US Army Corps

of Engineers

Waterways Experiment

Station

\title{
Bench-Scale Investigation of Composting for Remediation of Explosives-Contaminated Soils from lowa Army Ammunition Plant, Middletown, lowa
}

by Kurt T. Preston, Roy Wade, WES

Kyoung S. Ro, Louisiana State University

Steve Seiden, North Carolina State University

Mary Bergess, University of Toledo

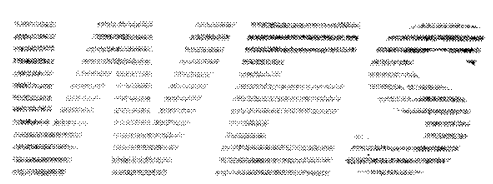

Approved For Public Release; Distribution Is Unlimited 
The contents of this report are not to be used for advertising, publication, or promotional purposes. Citation of trade names does not constitute an official endorsement or approval of the use of such commercial products.

The findings of this report are not to be construed as an official Department of the Army position, unless so designated by other authorized documents. 


\title{
Bench-Scale Investigation of Composting for Remediation of Explosives-Contaminated Soils from lowa Army Ammunition Plant, Middletown, lowa
}

by Kurt T. Preston, Roy Wade

\author{
U.S. Army Corps of Engineers \\ Waterways Experiment Station \\ 3909 Halls Ferry Road \\ Vicksburg, MS 39180-6199 \\ Kyoung S. Ro \\ Louisiana State University \\ Baton Rouge, LA 70803 \\ Steve Seiden \\ North Carolina State University \\ Raleigh, NC 27607 \\ Mary Bergess \\ University of Toledo \\ Toledo, OH 43606
}

Final report

Approved for public release; distribution is unlimited 


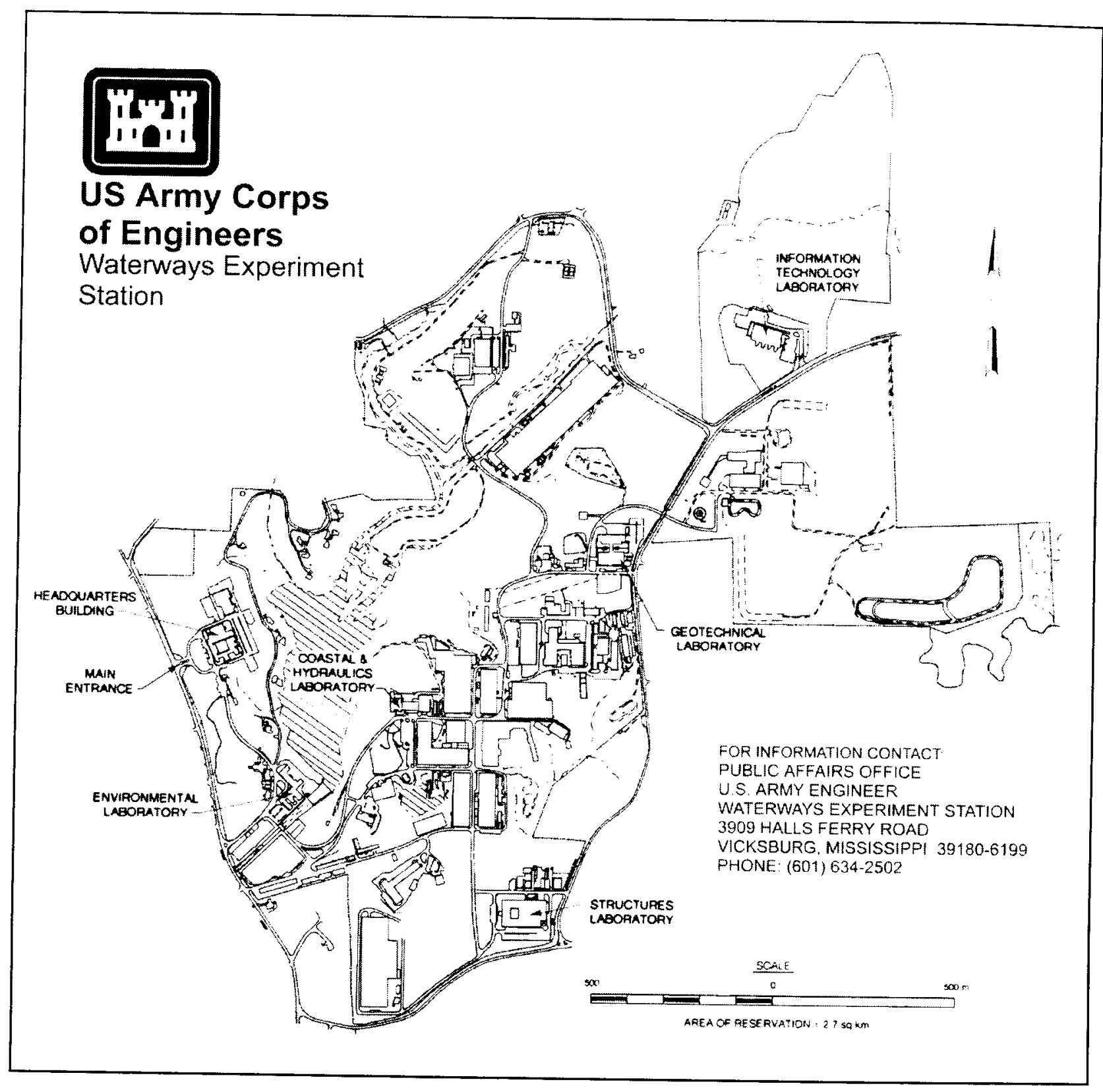

\section{Waterways Experiment Station Cataloging-in-Publication Data}

Bench-scale investigation of composting for remediation of explosives-contaminated soils from lowa Army Ammunition Plant, Middletown, lowa / by Kurt T. Preston ... [et al.] ; prepared for Department of
Defense, lowa Army Ammunition Plant.

49 p. : ill. ; $28 \mathrm{~cm}$. - (Technical report ; EL-98-7)

Includes bibliographical references.

1. Compost - Design. 2. Soil remediation - lowa - Middletown. 3. Explosives - Environmental aspects - lowa - Middletown. I. Preston, Kurt T. II. United States. Army. Corps of Engineers. III. U.S. Army Engineer Waterways Experiment Station. IV. Environmental Laboratory (U.S. Army Engineer Waterways Experiment Station) V. United States. Dept. of Defense. VI. lowa Army Ammunition Plant (U.S.) VII. Series: Technical report (U.S. Army Engineer Waterways Experiment Station) ; EL-98-7. TA7 W34 no.EL-98-7 


\section{Contents}

Preface ....................... vi

1 -Introduction ..................... 1

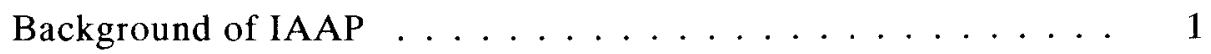

Site History . . . . . . . . . . . . . . . . . . 3

Former Line 1 Impoundment . . . . . . . . . . . 3

Line 800 Pink Water Lagoon . . . . . . . . . . . . 4

Site Contamination .................... 4

Former Line 1 Impoundment . . . . . . . . . . . . . 4

Line 800 Pink Water Lagoon . . . . . . . . . . . 5

Purpose ...................... 5

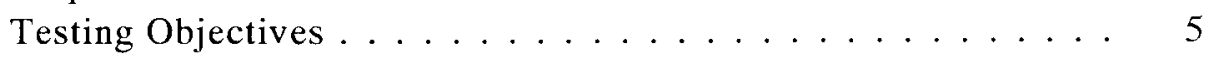

Scope of Work .................... 6

2-Remediation Composting Process Parameters ........ 7

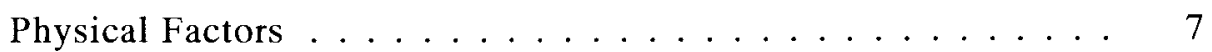

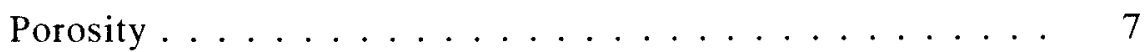

Free airspace .................... 8

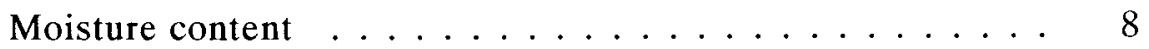

Particle size ....................... 9

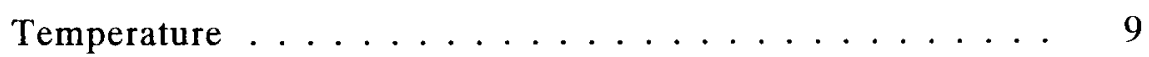

Chemical Factors . . . . . . . . . . . . . . 10

Contaminated soil loading . . . . . . . . . 10

Carbon to nitrogen ratio $(\mathrm{C} / \mathrm{N}) \ldots \ldots \ldots \ldots$

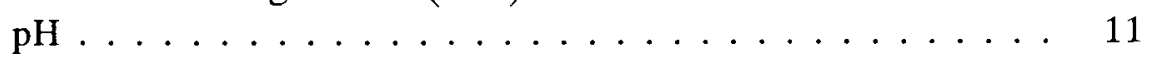

Biological Factors . . . . . . . . . . . . . . . 11

Biodegradability and biodegradation rate ........ 11

Aeration ..................... 12

3 -Respirometric Study . . . . . . . . . . . . . . . 13

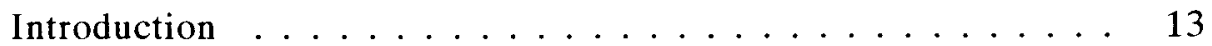

Materials and Methods .................. 14

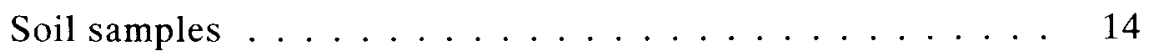

Compost mixtures ................... 16 
Respirometer procedure ................ 17

Physicochemical parameters . . . . . . . . . . . 17

Explosive analysis .................. 19

Half-life estimations for explosives . . . . . . . . . . . . 19

Results and Discussion . . . . . . . . . . . . . . 19

4 -Bench-Scale Composting Study . . . . . . . . . . . 21

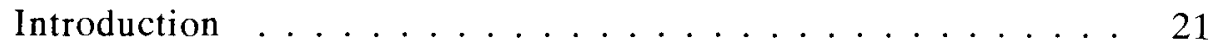

Materials and Methods . . . . . . . . . . . . 22

Bench-scale reactor system ................. 22

University of Minnesota compost reactor system . . . . . 23

Compost mixing procedure ............... 24

Results and Discussion . . . . . . . . . . . . . 25

Bench-scale reactor system ................ 25

University of Minnesota compost reactor system . . . . . 32

5 -Conclusions and Recommendations ............ 36

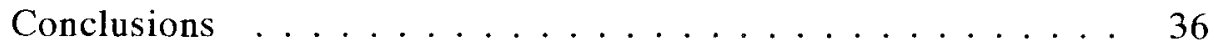

Recommendations .................. 37

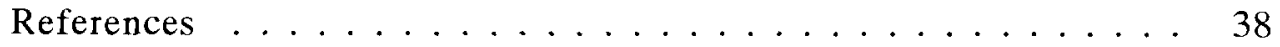

SF 298

\section{List of Figures}

Figure $1 . \quad$ Location of IAAP $\ldots \ldots \ldots \ldots 2$

Figure 2. Location of former Line 1 Impoundment and Line 800 Pink Water Lagoon areas . . . . . . . . . . . . . 3

Figure 3. Schematic diagram of bench-scale batch compost reactor system ................. 22

Figure 4. Schematic diagram of University of Minnesota compost reactor system . . . . . . . . . . 23

Figure 5. Physicochemical properties for Mixtures 3 and $4 \ldots 25$

Figure 6. Cow mixture core temperature profile . . . . . . 26

Figure 7. Cow mixture overall process temperature profile . . . 27

Figure 8 . Cow mixture cumulative aeration ......... 27

Figure 9. Pig mixture core temperature profile . . . . . . . 28

Figure 10. Comparison of cow and pig mixtures core temperature . . 29

Figure 11. Pig mixture overall process temperature profile . . . . . 29 
Figure 12. Pig mixture cumulative aeration . . . . . . . 30

Figure 13. Average explosive analysis results for Mixtures 3

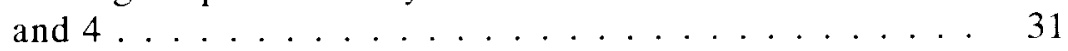

Figure 14. University of Minnesota $\mathrm{O}_{2}$ and $\mathrm{CO}_{2}$ headspace rates .................. 33

Figure 15. University of Minnesota core temperature profile . . . . 33

Figure 16. University of Minnesota initial and final TNT concentration .................. 34

Figure 17. Radiolabeled $\mathrm{O}_{2}$ and $\mathrm{CO}_{2}$ headspace rates ...... 35

Figure 18. Radiolabeled core temperature profile . . . . . . 35

\section{List of Tables}

Table 1. Physical Characteristics of Lagoon 800 and Line 1 Impoundment Soils . . . . . . . . . . 15

Table 2. Explosive Results - IAAP Line 1 Impoundment Soil . . 16

Table 3. Respirometric Results - Composition and Physiochemical Properties of the Compost Mixtures . . 16

Table 4. Respirometric Biodegradation Kinetic Coefficients of the Compost Mixtures . . . . . . . . . . . 17

Table 5. Bench-Scale - Compost Composition of Mixtures 3

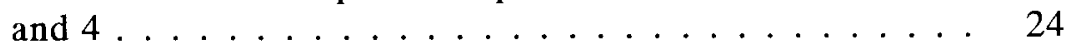

Table 6. Radiolabeled - Compost Composition for Mixture 4 . . 24

Table 7. Bench-Scale - Explosive Analysis for Mixtures 3

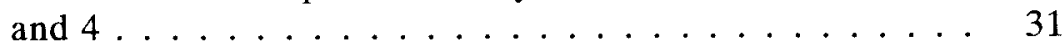




\section{Preface}

The study herein was conducted as a part of the Bench Compost Implementation Study. This report was prepared at the U.S. Army Engineer Waterways Experiment Station (WES) in cooperation with the Iowa Army Ammunition Plant (IAAP), Middletown, IA, and the U.S. Army Corps of Engineers, Omaha District. Program Manager for IAAP was Mr. Leon Baxter. Program Manager for the Omaha District was Mr. Kevin M. Howe. Project Managers for WES were Dr. Kurt T. Preston and Mr. Roy Wade.

The bench-scale studies were conducted between October 1994 and July 1996 in the WES Environmental Laboratory (EL). This report was written by Dr. Kurt T. Preston and Mr. Roy Wade, Environmental Restoration Branch (ERB), Environmental Engineering Division (EED), EL, WES; Dr. Kyoung S. Ro, Louisiana State University; Mr. Steve Seiden, North Carolina State University; and Dr. Mary Bergess, University of Toledo. Mr. James Davis, Contract Student from Mississippi State University, provided laboratory support.

The report was prepared under the direct supervision of Mr. Daniel E. Averett, Chief, ERB, and under the general supervision of Mr. Norman R. Francingues, Jr., Chief, EED, and Dr. John Harrison, Director, EL.

At the time of publication of this report, Director of WES was Dr. Robert W. Whalin. Commander was COL Robin R. Cababa, EN.

This report should be cited as follows:

Preston, K. T., Wade, R., Ro, K. S., Seiden, S., and Bergess, M. (1998). "Bench-scale investigation of composting for remediation of explosives-contaminated soils from lowa Army Ammunition Plant, Middletown, Iowa," Technical Report EL-98-7, U.S. Army Engineer Waterways Experiment Station, Vicksburg, MS. 


\section{Introduction}

The manufacturing process of conventional munitions has resulted in the generation of explosives-contaminated soils at various military installations. The principal explosive contaminants are 2,4,6-trinitrotoluene (TNT), hexahydro-1,3,5-trinitro-1,3,4-triazine (RDX), and octhydro1,3,5,7-tetranitro-1,3,5,7-tracine (HMX). The Iowa Army Ammunition Plant (IAAP) is one of many military installations that provide materials to the Army's weapon systems. The production operations of these weapons used explosive materials and lead-based initiating compounds (Jaycor 1993).

Because of the potential for groundwater contamination and the subsequent migration of explosives, treatment of the explosives-contaminated soils at several sites at IAAP is necessary to protect the environment and avoid costly actions in the future. Incineration and composting are demonstrated technologies for the remediation of explosives-contaminated soils. However, incineration is publicly undesirable and essentially economically unfeasible for remediation of small sites. Composting was the selected technology that was evaluated for the remediation of the explosives-contaminated soils at IAAP. The results of the bench-scale study are presented.

\section{Background of IAAP}

The IAAP is located in Middletown, IA, $140 \mathrm{~km}$ (87 miles) southwest of Davenport, IA, $167 \mathrm{~km}$ (104 miles) west of Peroria, IL, and $121 \mathrm{~km}$ ( 75 miles) south of Iowa City, IA (Figure 1). IAAP daily operations are managed by Mason and Hanger-Silias Company, Incorporated, under the guidance of the U.S. Army Armament, Munitions, and Chemical Command, Rock Island, IL. IAAP has provided manufacturing support to the Army for the production of ammunition items since 1941. IAAP is currently operating to load, assemble, and pack ammunition items, including projectiles, mortar rounds, warheads, demolition charges, antitank mines, antipersonnel mines, and the components of these munitions, including primers, detonators, fuses, and boosters. The loading, assembling, and packaging operations use explosive materials and lead-based initiating 


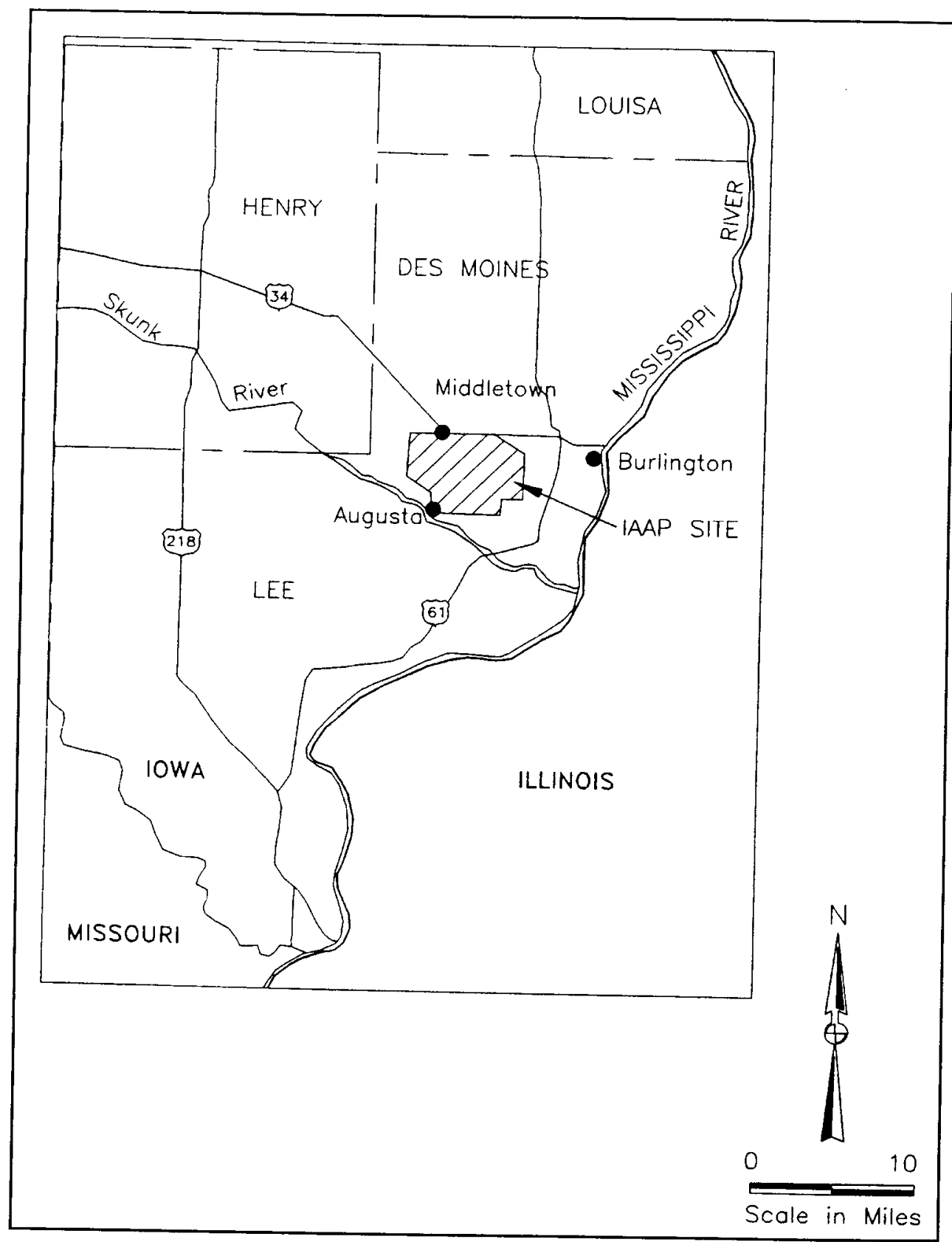

Figure 1. Site location map of IAAP (Source: Dames and Moore)

compounds (Jaycor 1993). The munition production at IAAP has resulted in the discharge of wastewater containing explosives and explosive by-products to the installation's surface waters, including holding ponds and impoundments. Figure 2 shows the location of each site. 


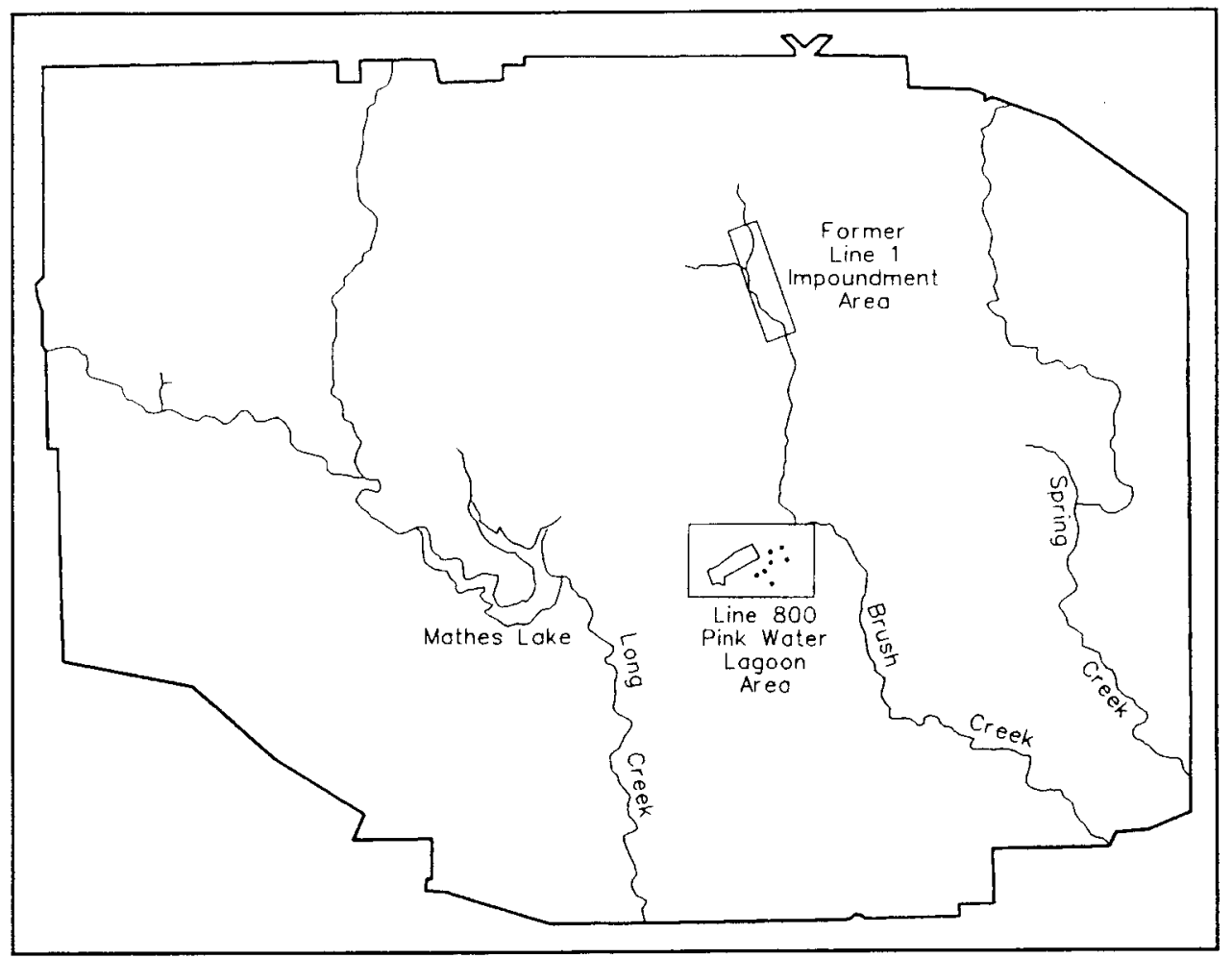

Figure 2. Location of former Line 1 Impoundment and Line 800 Pink Water Lagoon areas (Source: Dames and Moore)

\section{Site History}

\section{Former Line 1 Impoundment}

The Line 1 facilities parallel the upper reaches of Brush Creek in the northeastern portion of the IAAP installation. Large quantities of explosive waste and pink water have been reported from Line 1 facility during the period of 1948 to 1975 . To control the effluent discharge problem in 1948, a 396-m (1,300-ft) continuous embankment covering 1.5 ha (3.6 acres) was constructed along the upper reaches of Brush Creek (Dames and Moore 1989). This embankment was breached after 1975 and is now inhabited by overgrown vegetation and small trees. During high streamflow, the impoundment may reach $732 \mathrm{~m}(2,400 \mathrm{ft})$ upstream covering 3.0 ha (7.5 acres) (SCS 1982).

The geology of the former Line 1 Impoundment was characterized by shallow borings in the vicinity of the site. The sediment material was classified as sandy, silty clay till, and silty clay loess at depths of 0.6 to $1.5 \mathrm{~m}$ ( 2 to $5 \mathrm{ft}$ ) deep. Limestone outcrops have been observed in the creek valley south of the former Line 1 Impoundment (Dames and Moore 1989). 


\section{Line 800 Pink Water Lagoon}

The Line 800 Pink Water Lagoon, constructed in the 1960s, borders Line 800 and an intermittent tributary to Brush Creek. The lagoon spans

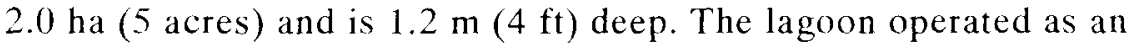
unlined waste site for the effluent from Line 800 and sludge from different processes around the IAAP installation. The lagoon was an active disposal site from 1943 to 1995 . The majority of the waste disposed of in the lagoon was from washdown activities, metal cleaning, and plating operations at facilities from Line 800 (Dames and Moore 1989). The lagoon is currently not in use and holds accumulated sediments and standing water. According to Dames and Moore (1989), the lagoon was later used as a settling pond to reduce particulate prior to discharge into Brush Creek.

The geology of the Line 800 Pink Water Lagoon is characterized from boreholes drilled into bedrock in the vicinity of the site. The overburden consists of 6.1 to $17.7 \mathrm{~m} \mathrm{(20} \mathrm{to} 58 \mathrm{ft})$ of clay-rich till with some sand and silt. The clays in the overburden are very stiff with relatively low permeability. A layer of sand ranging from 3.4 to $5.8 \mathrm{~m}$ (11 to $19 \mathrm{ft}$ ) thick was encountered. The bedrock underlying this area consists of fossiliferous limestone interbedded with layers of shaley clay and silt. The bedrock surface appeared weakened, and the upper portion of the limestone bedrock exhibits enhanced permeability (Dames and Moore 1989).

\section{Site Contamination}

Soils at the Former Line 1 Impoundment and Line 800 Pink Water Lagoon sites were tested for explosives, metals, and other organic analytes. These compounds and elements are known to have carcinogenic, mutagenic, or other adverse effects on living organisms.

\section{Former Line 1 Impoundment}

The soil at the Former Line 1 Impoundment had elevated levels of explosives. Explosive contaminants detected were RDX at concentrations ranging from 4 to $400 \mathrm{mg} / \mathrm{kg}$ and HMX ranging from 1.4 to $61 \mathrm{mg} / \mathrm{kg}$. The $H M X$ concentration was not significant, since the action level is $51,000 \mathrm{mg} / \mathrm{kg}$. The action levels for TNT, RDX, and 1,3,5-trinitrobenzene (TNB) were 196,53 , and $102 \mathrm{mg} / \mathrm{kg}$, respectively. Even though the explosive concentrations decreased laterally along the creek, elevated concentrations were measured as far as $23 \mathrm{~m}(75 \mathrm{ft})$ west of the creek for HMX and $366 \mathrm{~m}(1,200 \mathrm{ft})$ for RDX. Sampling on the east side of the creek was limited due to drill rigs along the creek. Therefore, symmetrical contamination was assumed on the east bank. All contamination seemed to be

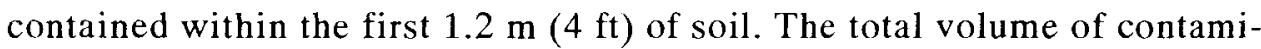
nated soil along Brush Creek was estimated to be $29,437 \mathrm{~m}^{3}\left(38,500 \mathrm{yd}^{3}\right)$. 
In addition, the soil was sampled for metals (i.e., copper, cadmium, and lead), and no significant concentrations were detected.

\section{Line 800 Pink Water Lagoon}

The surrounding soils and sediments at the Line 800 Pink Water Lagoon have elevated levels of explosives and perhaps other organic analytes. Explosive contaminants detected were RDX at a concentration of $800 \mathrm{mg} / \mathrm{kg}$, HMX at $110 \mathrm{mg} / \mathrm{kg}, 2,4,6 \mathrm{TNT}$ at $2,000 \mathrm{mg} / \mathrm{kg}$, and TNB at $200 \mathrm{mg} / \mathrm{kg}$. The highest concentration of explosives was detected in a former sludge dumping area, located in the southwest portion of the lagoon. These contaminants exceeded the action limit except for HMX. The significant contaminant concentration appeared within the first $0.6 \mathrm{~m}(2 \mathrm{ft})$ of the lagoon. Beyond $0.6 \mathrm{~m}(2 \mathrm{ft})$, the concentration dropped with depth, and no contamination was detected beyond $3 \mathrm{~m} \mathrm{(10} \mathrm{ft).} \mathrm{The} \mathrm{total} \mathrm{volume}$ of contaminated soil estimated at the Line 800 Pink Water Lagoon was $25,232 \mathrm{~m}^{3}\left(33,000 \mathrm{yd}^{3}\right)$. Unfortunately, the lagoon is storing $6.2 \times 10^{6} \mathrm{~L}$ $\left(1.63 \times 10^{6} \mathrm{gal}\right)$ of water that requires removal prior to initiation of any soil remediation process. The water is also considered to be contaminated with RDX and TNT.

\section{Purpose}

The purpose of this report is to document and present the results of the respirometric, bench-scale composting, and TNT radiolabeled tests performed as a part of the comprehensive remediation composting study. The results of this study will be provided to assist with the design of a pilot-l field-scale remediation compost system at IAAP.

\section{Testing Objectives}

The objective of this study was to evaluate and select the best combination of amendments, contaminated soils, and bulking agents to be utilized in the composting technology for remediating soils contaminated with the explosives TNT, HMX, and RDX. The objective of the respirometric test was to provide a general indication of biological activity within each compost mixture. Respirometry also was used as a tool for the specific screening of compost mixtures for the IAAP soil. The objective of the bench-scale compost reactor test was to extend the respirometric study, evaluating the applicability of the screened compost mixtures for degrading explosive compounds under actual composting environments prior to the pilot-/field-scale implementation. The objective of the radiolabeled study was to provide insight into the apparent degradation of the explosive contaminant during the composting process. 


\section{Scope of Work}

The scope of work includes a survey of locally available sources of amendment and bulking agents to be used for testing on the former Line 1 Impoundment and/or Line 800 Pink Water Lagoon soils and collection of soil samples at these sites. An initial screening of eight compost mixtures was performed to determine if any biological activity will occur using the respirometer and to select an optimum compost mixture for further evaluation. The bench-scale compost test was run to further validate the respirometric test results under actual composting environments. The University of Minnesota investigated the degradation of TNT using the selected mixture and the radiolabeled method. 


\section{Remediation Composting Process Parameters}

Successful design and operation of the remediation composting requires careful consideration of numerous factors affecting the process. The factors can be divided into three classes: physical, chemical, and biological. Physical factors define the structure of the compost matrix. Chemical factors consider the adequacy of substrates and the toxic effects of contaminants on the compost biomass. Biological factors define biodegradability and the biodegradation rate. Careful choice of a composting system with proper thermodynamic properties ensures the optimal thermophilic conditions (Preston, Seiden, and Ro 1997).

\section{Physical Factors}

\section{Porosity}

Porosity is a measure of pore or void space between solid particles in a bed and is defined as the ratio of void volume to the total bed volume in a system. It may be represented as a fraction or on a percentage basis. Porosity is important in compost systems for a number of reasons. The pore space provides a conduit for nutrient movement through the compost pile, space for the growth of microbial communities, and a reservoir for moisture held in the compost mixture.

The gas/liquid ratio has a profound impact on the efficiency of the compost operations and the efficacy of the treatment process. When the pore space is completely filled with water, oxygen within the system may become limited, and the compost system will become anaerobic. Also, the physical strength of the compost matrix will be undermined. Although this example is extreme, it highlights the importance of the interaction of solid particles, pore space, and the free airspace (FAS) in the definition of the physical nature of the compost matrix. 


\section{Free airspace}

The FAS is the ratio of the empty pore space $\left(V_{a}\right)$, or void volume not occupied by water, to the total volume. FAS is that portion of the pore space that is occupied by gas phase. Research indicates that the optimal biological activity occurs with an FAS ranging from 0.20 to 0.35 (Haug 1993). FAS is critical for the movement of oxygen and other gases into and through the compost matrix by either diffusion, convection, or forced ventilation.

The FAS may be managed by selection of the amendments and bulking agents, which are perhaps two of the most critical design decisions. The selection of these influence the nature of the compost, the efficiency of the operation, and the economics of the system.

In general, FAS begins to become available within the pore space in most compost systems at approximately 40-percent solids (Haug 1993; Golueke 1991). Thus, 40-percent solid content is generally considered as the maximum for most compost systems without augmentation by forced aeration.

\section{Moisture content}

An understanding of the role of water in compost design is of paramount importance. Beyond the role of water as a biochemical solvent, water in compost systems has an even larger multifaced role. Water plays a key role in the cooling of compost systems. Also, moisture content influences the nutrient movement and the compost matrix structure.

As a biochemical solvent, aqueous solutions are theoretically the ideal media for biological activity. In a completely mixed aqueous system, substrate is instantly available to the microbial community in equal concentration. When nutrients are added to the system, the biomass will be active and immediately utilize the available substrate. However, in aqueous aerobic systems, oxygen is often the limiting substrate due to its low solubility in aqueous solutions. Aqueous bacterial reactor systems generally attempt to improve oxygen transfer into solution by physical agitation or sparging of air.

Compost, a highly active aerobic system, can also suffer from oxygen limitation. As a result, proper management of the air and water within the compost pore volume is critical.

The optimal moisture content reported by researchers varied from 45 to 90 percent (Biddlestone et al. 1987; Haug 1993). The reported optimal moisture content varied because of the widely varying water absorption capacity of soil particles and composting materials used in research (Mathur 1991). Generally, a moisture content of about 45 to 65 percent is used. Above this range, the pore space will be filled with water, or at the 
very least, water tension in the pore space hinders the movement of gases between pores so that oxygen in the pore space becomes depleted. Below this range, moisture is not available to the microbial communities. The water remaining becomes associated with the solid particles due to the matrix potential arising from the capillary forces and adsorption. This water is held so tightly that it may be unavailable for utilization by microbes. Consequently, moisture may be present in the matrix, but the lack of moisture available to the microbial communities results in growthrate limitations and a loss of process efficiency.

\section{Particle size}

Various shredders and other mixing devices are used to break down and homogenize the compost materials into smaller and manageable sizes.

Since most of the composting microbial activities occur on the surface of the substrate particles, smaller size particles, which offer larger surface area, appear to enhance the microbial reactions. However, the movement of oxygen and water may be hindered in narrow interstitial spaces between the small particles packed together tightly. Generally, particle sizes between 1.3 and $5.0 \mathrm{~cm}$ are used for composting (Forster and Wase 1987). Small particles are used for forced-aeration compost systems, and large particle sizes are appropriate for windrow systems.

\section{Temperature}

Temperature is an important indicator in composting. As the microorganisms in a compost degrade organic substrates, heat is generated as a by-product of microbial breakdown of the organic substrate raising the compost temperature to the desired thermophilic conditions. Microbial activities and chemical reactions are usually faster at higher temperatures. For municipal solid wastes (MSW), retention of heat is also necessary in order to sanitize the wastes. The retention and continual generation of heat are dependent upon the configuration, size, and insulating property of composting systems, ambient temperature, and the heat values of substrates. Although higher temperature is beneficial in many ways, the microorganisms and enzymes are inactivated, and the composting process will stop beyond $70{ }^{\circ} \mathrm{C}$. Above $60{ }^{\circ} \mathrm{C}$, most mesophiles, including fungi, will be destroyed or inactivated, and the decomposing activity is carried out mainly by actinomycetes. After readily available substrates such as starches, sugars, lipids, and proteins have been consumed, the compost temperature will fall below $60{ }^{\circ} \mathrm{C}$ and will allow fungi and actinomycetes to attack cellulose and lignin portions of the substrates. Recently, researchers agreed that 55 to $60^{\circ} \mathrm{C}$ is the optimal temperature range (Bollen 1985; Finstein and Miller 1985). 


\section{Chemical Factors}

\section{Contaminated soil loading}

The economics of composting systems is primarily based on the amount of contaminated soil processed during a given time period. The higher the ratio of contaminated soil in a unit volume of compost given an equivalent microbial activity, the lower the overall cost of the system on a unit basis. However, this economic incentive must be carefully balanced with the possible inhibition by the contaminants on the compost of microbial activities and for the decrease in compost temperature simply due to replacing organic substrates with mostly inert soil. Loading the system with an excess of inhibitory contaminant slows microbial activity and results in an increase of composting time or may cause a total process upset. As a result, the composting process may not be able to reach or maintain a stable thermophilic state for the desired reaction time due to lack of organic substrates.

\section{Carbon to nitrogen ratio $(\mathrm{C} / \mathrm{N})$}

Compost microorganisms require adequate levels of carbon (C) sources and nutrients including nitrogen $(\mathrm{N})$, phosphorous, sulfur, and other trace minerals and growth factors. Among these, $\mathrm{C}$ and $\mathrm{N}$ are usually the limited substrates, while other elements and nutrients are abundant in composting processes. Chemical elemental analysis of soil microorganisms revealed that the cells in general contain about 50 -percent $C, 5$-percent $\mathrm{N}$, and 0.25 - to 1-percent phosphorous on a dry weight basis (Alexander 1977). Assuming about one-half to two-thirds of the carbon is converted to carbon dioxide $\left(\mathrm{CO}_{2}\right)$ and the rest to cell mass, the required $\mathrm{C} / \mathrm{N}$ ratio would be about 23 to 35 . The optimal $\mathrm{C} / \mathrm{N}$ ratios for different composting materials range from 20 to 35 (Haug 1993).

If the initial $\mathrm{C} / \mathrm{N}$ ratio is too high (i.e., low nitrogen level), the microorganisms pass through many life cycles to achieve a stable state (i.e., $\mathrm{C} / \mathrm{N}$ of about 10). This may not be desirable for conventional MSW composting because it reduces the substrate stabilization rate. It may, however, be beneficial for remediation composting because dead microorganisms themselves are organic substrates and support endogenous activities for long periods. If the $\mathrm{C} / \mathrm{N}$ ratio is too low, nitrogen will be lost as ammonia, which may reach toxic levels and raise the $\mathrm{pH}$ of the compost mix. For a compost mix with high $\mathrm{C} / \mathrm{N}$ ratio, ammonia-releasing substrates such as blood, urine, or urea can be added. If phosphorous and other nutrient concentrations are low, as in cases of using industrial solid wastes as substrates, these elements need to be supplemented in order to avoid unnecessary rate limitations. 
pH of the compost matrix must be near neutral (i.e., pH of 7). For all practical purposes, microbial growth is severely limited at $\mathrm{pH}$ values less than 3 or greater than 11 . The optimum pH of composting has been reported to be between 6.0 and 8.5 (Fitzpatrick 1993). At higher pH (strongly basic), ammonium ions (nitrogen source) are lost as ammonia, and essential elements such as calcium and magnesium may not be available to microorganisms due to precipitation as insoluble metal hydroxides or carbonates. At lower $\mathrm{pH}$ (strongly acidic), toxic metals, aluminum, copper, zinc, etc., leach from minerals and substrates and may stop the composting process.

Overall, compost mix $\mathrm{pH}$ may be adjusted with cosubstrates or other $\mathrm{pH}$-adjusting chemicals such as lime and baking soda if the initial $\mathrm{pH}$ falls outside the optimum range. For instance, wood wastes and sludges from pulp and paper mills may have a low pH of 5 to 6 and high $\mathrm{C} / \mathrm{N}$. Addition of ammonia-releasing substrates such as urine or urea will neutralize the acidity and provide necessary nitrogen to microorganisms. Fortunately, composting has the unique ability to buffer both high and low $\mathrm{pH}$ to a neutral range as composting proceeds. This phenomenon may be explained by the release of carbon dioxide $\left(\mathrm{CO}_{2}\right)$ and ammonia $\left(\mathrm{NH}_{3}\right)$ as a result of organic decomposition. Therefore, $\mathrm{pH}$ adjustment is usually not required and is not a common practice in composting systems.

\section{Biological Factors}

\section{Biodegradability and biodegradation rate}

Substrate biodegradability determines the amount of substrate energy available to drive the composting process, the requirement for additional energy amendments, the stoichiometric oxygen demand, the air demand to remove heat from the process, and the final product mass. Literature values for biodegradability of substrates vary widely; for instance, 28 percent for steer manure to 68 percent for chicken manure (Klein 1972) or 21.7 percent for newsprint to 81.9 percent for food wastes (Kayhanian and Tchobanoglous 1992). Chandler et al. (1980) reported that the lignin content was the single most important factor influencing the biodegradability of a compost system.

In contrast to MSW, which requires a long retention time (typically more than 90 days of composting) to achieve adequate stabilization, long retention time may not be required nor desired for remediation of soils contaminated with explosive compounds. Most of the previous remediation composting studies indicated that less than 30 days were required to substantially degrade or transform TNT, RDX, and other explosive compounds by aerobic composting (Doyle and Isbister 1982; U.S. Army Toxic 
and Hazardous Material Agency 1988; Garg, Grasso, and Hoag 1991; Pennington 1995).

\section{Aeration}

Aeration is important in two aspects: oxygen supply to aerobic microorganisms and cooling/drying of the compost by evaporation of water. For nonmechanical aeration systems, oxygen may be transported via molecular diffusion and free convection of air movement due to temperature gradients. Oxygen may also be supplied by forcing air through the compost matrix or mechanically mixing the compost intermittently to enhance oxygen transfer. Aeration is also used to dry and subsequently cool the compost by promoting evaporation of water. Approximately 10 to 30 times more aeration is required for drying of 20 -percent solids than for biological oxidation (Haug 1993). Composters typically use about $1 \mathrm{~m}^{3}$ air $/ \mathrm{kg}$ volatile solids-day. 


\section{Respirometric Study}

\section{Introduction}

Respirometry is a technique for determining oxygen consumption in an aerobic environment (Mahendraker and Viraraghavan 1995) under conditions that avoid rate limitations from lack of nutrients, oxygen, moisture, imbalanced $\mathrm{pH}$, or inadequate seed microbes. During aerobic respiration, microbial activity results in mineralization of organic matter into $\mathrm{CO}_{2}$ and water, as well as utilization of the substrate as a carbon and energy source for cell growth and maintenance. Monitoring of respiration rates in microbial populations or biomass is a useful tool for measuring the biodegradation of organic matter, that has been applied to wastewater treatment, composting, and bioremediation.

Respirometry, as mentioned earlier, provides biodegradation rates, the rates at which microorganisms degrade different organic substrates (Flathman and Nowakowski 1995; Carlsson 1993; Vanrolleghem and Verstraete 1993; Kappeler and Gujer 1992; Grady et. al. 1989). Respirometric data can be used to approximate the short-term biochemical oxygen demand (SBOD) and oxygen uptake rate (OUR) and to estimate the standard biochemical oxygen demand (Spanjers, Olsson, and Klapwijk 1994; Vanrolleghem and Spanjers 1994; Jacobi and Fussa 1993). In addition, respirometry helps to identify the toxic and inhibitory effects that the organic substrate may have on the microorganisms (Boening, Hendricks, and Rossignol 1995; Spanjers, Temmink, and Klapwijk 1994; Herricks et al. 1991).

Finally, respirometry can be used as a tool for determining treatment plant design parameters for sizing blowers, aerators, and composting piles (Hunter, Johnson, and Carns 1995; Brouwer, Klapwijk, and Keesman 1994; Arthur and Meredith 1993; Klapwijk, Spanjers, and Temmink 1993; Watts and Garber 1993; Rozich and Guady 1992). Several reviews are available that discuss different techniques and applications for respirometry (Mahendraker and Viraraghavan 1995; Arthur and Arthur 1994). To date, no significant research has been conducted on using a respirometry to provide insight on contaminated soils, in particular, soils contaminated with explosives (Mahendraker and Viraraghavan 1995). 
In this study, a respirometric technique was used as a first step to determine the optimal compost mix for treating explosives-contaminated soils from the Rockeye site. Eight compost mixtures were evaluated for their total oxygen utilization and uptake rates as well as the degradation of TNT, HMX, RDX, 4-amino-2,6-dinitrotoluene (4A-DNT), and 2-amino4,6-dinitrotoluene (2A-DNT).

\section{Materials and Methods}

\section{Soil samples}

A 97-L (25-gal) sample consisting of five 20-L (5-gal) buckets was collected from the vicinity of the Former Line 1 Impoundment Lagoon (latitude $40^{\circ} 48.32 \mathrm{~N}$ and longitude $91^{\circ} 13.61 \mathrm{~W}$ ) at an approximate elevation of $205 \mathrm{~m}(674 \mathrm{ft})$. Three definite soil horizons were observed. Horizon $\mathrm{A}_{1}$ was a dark sandy loam soil approximately $20 \mathrm{~cm}\left(8 \mathrm{in}\right.$.) thick. Horizon $\mathrm{A}_{2}$ was a layer of red-colored soil of the same texture less than $2.54 \mathrm{~cm}$ ( 1 in.) thick. The red color was presumed indicative of explosive contamination. As a result, this layer was inferred to contain the highest level of contamination. Horizon B appeared to be a clay soil. Given the gray mottled appearance of Horizon B, it was further presumed that the soil is often in a state of oxygen-reducing conditions. Three 20 -L (5-gal) bucket samples were taken from Horizons $A_{1}$ and $A_{2}$; two 20-L(5-gal) bucket samples were taken from the Horizon $B$. TNT field kits confirmed the presence of explosive contaminates.

Upon receipt at the U.S. Army Engineer Waterways Experiment Station (WES), the sample was air-dried and homogenized using a Gilson splitter. Agglomerations were crumbled, but not pulverized using a pestle. The total sample weight after homogenization was approximately $90 \mathrm{~kg}$. Consolidation allowed the samples to be placed within four 20 -L (5-gal) sealed buckets. The homogenized sample was classified as a loam to silty loam using the hygrometric particle size determination (sand - 31.8 percent, silt -49.4 percent, colloidal clay -8.36 percent, and noncolloidal clay - 10.4 percent). The physical characteristics of Lagoon 800 and Line 1 Impoundment soils are presented in Table 1.

From the homogenized bulk sample, a subsample was dry-sieved and characterized for the contaminant concentration found in each fraction of sand, silt, and clay. The results indicated the explosive concentrations in each of the fractions of sand, silt, and clay. Table 2 shows the totals of explosive concentration of Line 1 Impoundment soil that appear to be representative of the contaminants found at the site. 


\begin{tabular}{|c|c|c|c|c|c|}
\hline \multicolumn{6}{|c|}{$\begin{array}{l}\text { Table } 1 \\
\text { Physical Characteristics of Lagoon } 800 \text { and Line } 1 \text { Impoundment Soils }\end{array}$} \\
\hline \multicolumn{3}{|c|}{$\begin{array}{l}\text { Color (Munsell Soil Color Chart) } \\
\mathrm{pH}\end{array}$} & \multicolumn{3}{|c|}{$\begin{array}{l}2.5 \text { YR 4/2, Dark Grayish Brown/5 YR 2.5/1, Black } \\
3.50 / 6.21\end{array}$} \\
\hline \multicolumn{6}{|c|}{ Average Densities of Fractions (oven-dried at $60^{\circ} \mathrm{C}$ ) (Lagoon $800 /$ Line 1 Impoundment) } \\
\hline \multicolumn{3}{|c|}{ Sample Description } & \multicolumn{3}{|c|}{ Average Density, g/cc } \\
\hline \multicolumn{3}{|c|}{ Bulk $<2.00 \mathrm{~mm}$, dry sieved } & \multicolumn{3}{|l|}{$2.59 / 2.57$} \\
\hline \multicolumn{3}{|c|}{ Bulk $<0.85 \mathrm{~mm}$, dry sieved } & \multicolumn{3}{|l|}{$2.58 / 2.57$} \\
\hline \multicolumn{3}{|c|}{ Bulk $<0.85 \mathrm{~mm}$, wet sieved } & \multicolumn{3}{|l|}{$2.60 / 2.57$} \\
\hline \multicolumn{6}{|c|}{ Sample Fractions (Lagoon 800/Line 1 Impoundment) } \\
\hline \multicolumn{6}{|c|}{ Dry-Sieve Analysis $(2,171.35 / 2,655.32 \mathrm{~g}$ as-is and $2,047.38 / 2,542.10 \mathrm{~g}$ Dry Wt.) } \\
\hline Sieve Fraction & Raw Wt., g & $\begin{array}{l}\text { Solids per } 1-g \\
\text { Sample }\end{array}$ & $\begin{array}{l}\text { Oven-Dried Wt., } \\
\text { g (Moisture } \\
\text { Test) }\end{array}$ & Percent Dry Fr & tion \\
\hline$>2.00 \mathrm{~mm}$ & $0.22 / 20.34$ & $1.0000 / 0.9862$ & $0.22 / 20.06$ & $0.01 / 0.79$ & \\
\hline $0.063-2.00 \mathrm{~mm}$ & $1851.97 / 1914.94$ & $0.9347 / 0.9596$ & $1730.99 / 1837.40$ & $84.55 / 72.28$ & \\
\hline$<0.063 \mathrm{~mm}$ & $299.14 / 582.5$ & $0.9574 / 0.9646$ & $286.41 / 561.88$ & $13.99 / 22.10$ & \\
\hline Gain (Loss) & $(20.02 / 137.54)$ & - & $(29.76 / 122.76)$ & $(1.45 / 4.83)$ & \\
\hline \multicolumn{6}{|c|}{ Wet-Sieve Analysis (2,601.39/2,830/63 g as-is, 2,152.35/2,607.71g Dry Wt.), 19.0 L rinse water } \\
\hline$>2.00 \mathrm{~mm}$ & $3.82 / 16.12$ & $0.7853 / 0.9218$ & $3.00 / 14.86$ & \multicolumn{2}{|l|}{$0.14 / 0.57$} \\
\hline $0.063-2.00 \mathrm{~mm}$ & $211.10 / 822.33$ & $0.6796 / 0.7667$ & $143.47 / 630.51$ & \multicolumn{2}{|l|}{$6.67 / 24.18$} \\
\hline $0.0025-0.063 \mathrm{~mm}$ & $2112 / 1767.6$ & $111.2 / 196.4 \mathrm{~g} / \mathrm{L}$ & $2065.23 / 1806.0$ & \multicolumn{2}{|l|}{$88.4 / 69.3$} \\
\hline$<0.0025 \mathrm{~mm}$ & - & - & - & \multicolumn{2}{|l|}{-} \\
\hline Gain (Loss) & - & - & $(59.15 / 156.34)$ & \multicolumn{2}{|l|}{$(2.75 / 5.99)$} \\
\hline \multicolumn{6}{|c|}{ Moisture Tests (oven-dried at $60^{\circ} \mathrm{C}$ ) } \\
\hline Sample & Initial Wt., $\mathbf{g}$ & Dry Wt., g & $\begin{array}{l}\text { Percent } \\
\text { Moisture }\end{array}$ & \multicolumn{2}{|l|}{ Percent Solids } \\
\hline $\begin{array}{l}\text { Bulk > } 2.00 \mathrm{~mm} \\
\text { dry-sieved }\end{array}$ & $0.22 / 2.90$ & $0.22 / 2.86$ & $0.00 / 1.38$ & \multicolumn{2}{|l|}{$100 / 98.62$} \\
\hline $\begin{array}{l}\text { Bulk }<0.063 \mathrm{~mm} \\
\text { dry-sieved }\end{array}$ & $6.21 / 8.76$ & $5.95 / 8.45$ & $4.26 / 3.54$ & \multicolumn{2}{|l|}{$95.74 / 96.46$} \\
\hline $\begin{array}{l}\text { Bulk }>2.00 \mathrm{~mm} \\
\text { wet-sieved }\end{array}$ & $3.74 / 0.51$ & $2.94 / 0.47$ & $21.39 / 7.84$ & \multicolumn{2}{|l|}{$78.61 / 92.16$} \\
\hline \multicolumn{6}{|c|}{ Hydrometer Procedure } \\
\hline Time & Temp., ${ }^{\circ} \mathrm{F}$ & \multicolumn{2}{|c|}{ Hydrometer Reading } & \multicolumn{2}{|c|}{ Reading Correction } \\
\hline $\mathrm{O} \mathrm{hr}$ & $92.3 / 73.4$ & \multicolumn{2}{|c|}{ - } & - & \\
\hline $40 \mathrm{sec}$ & $92.3 / 73.4$ & $35.0 / 33.0$ & & $39.9 / 34.1$ & \\
\hline $2 \mathrm{hr}$ & $72.5 / 69.8$ & $11.0 / 9.0$ & & $11.9 / 9.4$ & \\
\hline $24 \mathrm{hr}$ & $68.9 / 68.9$ & $6.5 / 4.0$ & & $6.7 / 4.2$ & \\
\hline $\begin{array}{l}\text { Percent (Silt + } \\
\text { Clay) }\end{array}$ & Percent Sand & Percent Silt & $\begin{array}{l}\text { Percent Clay } \\
\text { (Coll + Noncoll) }\end{array}$ & Colloidal Clay & $\begin{array}{l}\text { Noncolloidal } \\
\text { Clay }\end{array}$ \\
\hline $79.7 / 68.1$ & $20.3 / 31.8$ & $55.9 / 49.4$ & $23.8 / 18.7$ & $13.4 / 8.4$ & $10.4 / 10.4$ \\
\hline USDA Classificatio & Silty Loam/Loam to & Ity Loam & & & \\
\hline
\end{tabular}




\begin{tabular}{|c|c|c|c|c|}
\hline \multicolumn{5}{|c|}{$\begin{array}{l}\text { Table } 2 \\
\text { Explosive Results - IAAP Line } 1 \text { Impoundment Soil }\end{array}$} \\
\hline $\begin{array}{l}\text { Contaminant, } \\
\mathrm{mg} / \mathrm{kg}\end{array}$ & Sand & Silt & Clay & Total \\
\hline TNT & 5.8 & 3.4 & 2.2 & 11.4 \\
\hline $\mathrm{HMX}$ & 4.9 & 33.8 & 64 & 102.7 \\
\hline RDX & 32.9 & 332 & 278 & 642.9 \\
\hline
\end{tabular}

\section{Compost mixtures}

From previous studies, WES determined that to characterize each compost treatment, total oxygen utilization and oxygen uptake rates for IAAP soil must be measured. Eight compost mixtures were evaluated, and two optimal compost mixtures were selected for the bench-scale composting experiment. Ingredients for these mixes are shown in Table 3. Each compost mixture used in the initial study contained by volume $(\mathrm{v} / \mathrm{v})$ 20 percent manure, 65 percent amendment, and 15 percent IAAP Line 1 Impoundment soil by wet weight. The amendments were cow and swine manures, while the bulking agents included cornstalks, sawdust, and woodchips. The compost mixes had $\mathrm{C} / \mathrm{N}$ ratios ranging from 28 to 62 , moisture contents ranging from 52 to 65 percent, and $\mathrm{pH}$ ranging from 6.3 to 7.6 (Table 3).

\begin{tabular}{|c|c|c|c|c|c|c|}
\hline \multicolumn{7}{|c|}{$\begin{array}{l}\text { Table } 3 \\
\text { Respirometric Result - Composition and Physiochemical Properties of the Compost } \\
\text { Mixtures }\end{array}$} \\
\hline $\begin{array}{l}\text { Mixture } \\
\text { Number }\end{array}$ & $\begin{array}{l}\text { Amendment and Bulking } \\
\text { Agents }\end{array}$ & $\mathrm{pH}$ & $\begin{array}{l}\text { Percent } \\
\text { Moisture }\end{array}$ & TVS & TKN & C/N Ratio \\
\hline 1 & Cow manure and sawdust & 6.91 & 52.31 & 84.8 & 5548 & 42 \\
\hline 2 & Swine manure and sawdust & 6.43 & 57.43 & 60.7 & 4210 & 40 \\
\hline 3 & Cow manure and cornstalk & 7.06 & 65.52 & 70.1 & 7029 & 28 \\
\hline 4 & Swine manure and cornstalk & 7.27 & 64.19 & 70.9 & 4791 & 41 \\
\hline 5 & Cow manure and sawdust/cornstalk & 7.13 & 55.66 & 60.9 & 5245 & 32 \\
\hline 6 & Swine manure and sawdust/cornstalk & 6.44 & 61.39 & 78.0 & 4572 & 47 \\
\hline 7 & Cow manure and woodchips & 7.55 & 59.72 & 70.5 & 5011 & 39 \\
\hline 8 & Swine manure and woodchips & 6.28 & 52.76 & 68.6 & 3077 & 62 \\
\hline
\end{tabular}




\section{Respirometer procedure}

A BI-1000 Electrolytic Respirometer (Bioscience, Inc., Bethlehem, PA) was used to collect oxygen-utilization data. This respirometer consisted of eight $1-\mathrm{L}$ reactor bottles, a reactor module, a water bath $\left(40^{\circ} \mathrm{C}\right)$, a temperature controller, a personal computer, and control software. Approximately $200 \mathrm{ml}$ of each mix was placed into a flask. The initial amounts of total volatile solids (TVS), total Kjeldahl nitrogen (TKN), TNT, RDX, HMX, 4A-DNT, and 2A-DNT for each treatment were determined by analyzing a portion of the remaining mix.

After 10 days, the compost was removed from each bottle and analyzed for final amounts of explosive, TVS, TKN, $\mathrm{pH}$, and moisture content. The half-life of each mix was calculated to determine which mix most effectively removed the explosives from the soil. In addition, the final respiration data were used to estimate the amount of oxidized carbon, which was later used to determine the substrate degradation rate and the specific biodegradation rate (SBR) of each mix (Table 4).

\begin{tabular}{|c|c|c|c|c|c|c|}
\hline \multicolumn{7}{|c|}{$\begin{array}{l}\text { Table } 4 \\
\text { Respirometric Biodegradation Kinetic Coefficients of the Compost Mixtures }\end{array}$} \\
\hline $\begin{array}{l}\text { Mixture } \\
\text { Number }\end{array}$ & $\begin{array}{l}\text { Total Oxygen } \\
\text { Consumed, } \mathbf{g}\end{array}$ & $\begin{array}{l}\text { Maximum } \\
\text { OUR, g/day }\end{array}$ & $\begin{array}{l}\text { Degraded } \\
\text { Organic-C, } \mathbf{g}\end{array}$ & $\begin{array}{l}\text { Initial } \\
\text { Organic-C, } \mathbf{g}\end{array}$ & \begin{tabular}{|l|} 
Substrate \\
Degradation \\
Rate \\
Coefficient \\
Day $^{-1}$ \\
\end{tabular} & SBR day ${ }^{-1}$ \\
\hline 1 & 2.22 & 0.664 & 0.81 & 10.44 & 0.008 & 0.008 \\
\hline 2 & 1.00 & 0.674 & 0.36 & 7.90 & 0.005 & 0.005 \\
\hline 3 & 3.60 & 1.006 & 1.31 & 5.72 & 0.026 & 0.023 \\
\hline 4 & 4.25 & 2.610 & 1.55 & 11.19 & 0.015 & 0.014 \\
\hline 5 & 3.95 & 0.991 & 1.44 & 7.04 & 0.023 & 0.020 \\
\hline 6 & 3.91 & 1.928 & 1.42 & 7.16 & 0.022 & 0.020 \\
\hline 7 & 3.00 & 1.217 & 1.09 & 10.23 & 0.011 & 0.011 \\
\hline 8 & 3.50 & 1.383 & 1.27 & 7.90 & 0.018 & 0.016 \\
\hline
\end{tabular}

\section{Physicochemical parameters}

Oxygen utilization. The BI-1000 was programmed to record data every $30 \mathrm{~min}$. This respirometer incorporates a potassium hydroxide trap to remove the $\mathrm{CO}_{2}$ respired by the biomass, resulting in the change of the pressure inside the flask. The change in pressure is proportional to oxygen utilization. The oxygen utilized was replaced with oxygen produced by electrolysis of water at $100 \mathrm{mg}$ per hour. The oxygen replacement was computer controlled. 
Oxygen uptake rate. OURs were determined from the oxygen utilization data collected by the BI-1000 respirometer. OURs were calculated by dividing the change in oxygen by the time interval for a specific change.

Moisture content. The moisture content was determined by ovendrying the compost at $104{ }^{\circ} \mathrm{C}$ for $24 \mathrm{hr}$, subtracting the final weight from the initial weight, and dividing the result by the initial weight (Greenburg, Clesceri, and Eaton 1992).

Total volatile solid. The TVSs were determined by placing the compost sample into a furnace at $550{ }^{\circ} \mathrm{C}$, subtracting the final weight from the initial weight, and dividing the result by the initial weight (Method 2540G Total, Fixed, and Volatile Solids and Semisolid Samples; Greenburg, Clesceri, and Eaton 1992).

Total Kjeldahl nitrogen. Three to five grams of compost were mixed together with $5 \mathrm{ml}$ of sulfuric acid in a $250-\mathrm{ml}$ polyethylene bottle. After agitating the bottle for $3 \mathrm{~min}, 245 \mathrm{ml}$ of double-distilled water was added. Twenty milliliters of sample was digested using a BD-46 Digestor. After digestion, the TKN values were measured on a Lachat instrument using QuikChem method 10-107-06-02-D.

Specific biodegradation rate. The SBR was calculated by dividing the grams of degraded carbon as $\mathrm{CO}_{2}$ by the grams of initially available carbon in dry weight and by the days of incubation. A similar method was described by Atkinson et al. (1996). The total amount of dry weight carbon can be estimated as follows (Haug 1993):

$$
\text { Dry Weight } C=(T V S / 1.8) * \text { Dry Weight }
$$

The mole ratio of $\mathrm{O}_{2}$ consumed to $\mathrm{CO}_{2}$ generated was about $16.5 / 16$, and this ratio was used to estimate $\mathrm{CO}_{2}$ generation based on $\mathrm{O}_{2}$ consumption data.

pH. Approximately $5 \mathrm{~g}$ of compost was mixed into a slurry using two to three times the amount of distilled deionized (DDI) water. The mixture was stirred twice before measuring it with a $\mathrm{pH}$ meter.

C/N Ratio. The carbon-to-nitrogen ratio was calculated using the following equation:

$$
C / N=\text { biodegradability factor } *\left(\text { TVS/1.8) } \div\left(T K N * 10^{-4}\right)\right.
$$

The biodegradability factor is assumed to be 0.5 (Haug 1993). The percent available nitrogen is the TKN value divided by 10,000 . 


\section{Explosive analysis}

Explosives were determined by SW846 Method 8330: Nitroaromatics and Nitroamines by high performance liquid chromatography (HPLC) (U.S.Environmental Protection Agency (USEPA) 1992). Samples were homogenized by stirring and extracted without drying. Chromatographic analysis was performed with a Perkin Elmer Integral 4000 HPLC using a C-18 Reverse Phase HPLC column (Supelco LC-18), $25 \mathrm{~cm}$ by $4.6 \mathrm{~mm}$ $(5 \mu \mathrm{m})$. Extraction was performed using acetonitrile.

\section{Half-life estimations for explosives}

The half-life estimations were determined by assuming the first-order equation,

$$
k=\ln \left(C_{o} / C_{t}\right) / t
$$

where,

$$
\begin{aligned}
k & =\text { first-order rate coefficient, days }{ }^{-1} \\
C_{o} & =\text { initial contaminant concentration, } \mathrm{mg} / \mathrm{kg} \\
C_{t} & =\text { contaminant concentration at time } t, \mathrm{mg} / \mathrm{kg} \\
t & =\text { composting time, days }
\end{aligned}
$$

Equation 3 was solved for $k$. The half-life (days) was then estimated from Equation 4.

$$
t_{1 / 2}=0.693 / k
$$

where $t_{1 / 2}$ equals half-life (days).

\section{Results and Discussion}

The IAAP soil was analyzed for explosives, but the explosive concentrations were low. Based on WES's experience, the biodegradation rates of each mix should display the same trends as long as the concentration of explosives does not inhibit microbial activity (Preston, Seiden, and Ro 1997). Therefore, the compost treatment was evaluated for SBR and OUR.

Table 4 displays the SBRs, the maximum OUR, and the first-order SBR coefficients. The SBR for each mixture was determined from the accumulated oxygen data from the respirometer. Mixture 3 had the highest SBR of $0.023 \mathrm{day}^{-1}$ and Mixture 2 had the lowest of $0.005 \mathrm{day}^{-1}$. From this data, the first choices for treatment to be considered would be Mixes 3, 5, 
and 6. However, Mixture 4 had the highest OUR of $2.6 \mathrm{~g}$ per day followed by Mixtures 6-8. Interestingly, Mixtures 3 and 5, which contain cow manure and cornstalk, had the highest SBR, while the mixtures that contain swine manure and cornstalk, Mixtures 4 and 6, had the highest OURs.

The substrate degradation rate coefficients ranged from 0.005 to $0.026 \mathrm{day}^{-1}$. Haug (1993) reworked a correlation for the substrate degradation rate coefficient at various temperatures for composting a mixture of garbage and dewatered, digested sludge cake as:

$$
k_{d}=0.00632 *(1.066)^{T-20}
$$

where

$$
\begin{aligned}
k_{d} & =\text { rate coefficient }, \mathrm{day}^{-1} \\
T & =\text { temperature, }{ }^{\circ} \mathrm{C}
\end{aligned}
$$

Equation 4 using $40^{\circ} \mathrm{C}$ of the respirometric test temperature predicts $k_{d}$ of $0.023 \mathrm{day}^{-1}$, which is within the rate coefficient range.

Eight compost mixtures were evaluated for their substrate utilization rates and degradation rates of explosive analyte and transformation products found in the IAAP soils. Compost Mixes 3 (cow manure, cornstalk, and soil) and 4 (swine manure, cornstalk, and soil) showed the fastest degradation potential for the explosives. Compost Mixture 3 showed the best biodegradation rate, and Mixture 4 showed the best respiration rate, while its biodegradation rate falls approximately in the middle of the eight treatments.

Although Mixture 6 (pig manure, cornstalk, and sawdust) was among the highest in terms of SBR and OUR, it was not selected because of the extra bulking agent ingredient. However, Mixture 6 may be effective in treating the explosives-contaminated soil. 


\section{Bench-Scale Composting Study}

\section{Introduction}

The preliminary success of the compost Mixtures 3 and 4 from the respirometric test was further evaluated under actual composting environments. A bench-scale remediation composting system that closely simulates the actual composting process was used to expand the respirometric study. The bench-scale study is expected to provide the preliminary feasibility, the fate of the contaminants, and the health risk of composted products. The pilot-scale studies can be initiated to cover the scale-up factors and the heterogeneity of field conditions, and finally successful field operations can be implemented.

The standard composting method of ASTM D5338 uses incubators to externally control the compost reactors at predefined temperatures $\left(35^{\circ} \mathrm{C}\right.$ for the first 16 days and $55^{\circ} \mathrm{C}$ for 28 days). With this externally predefined temperature control, reproducibility of data may be improved; however, many leading experts argue that it may not adequately represent the actual composting process in which self-heating is induced. A relatively high surface area to volume ratio compared with field or pilot compost piles results in high conductive and convective heat loss. In some systems, the heat generated from degrading organic substrates may not be enough to raise and maintain the thermophilic compost temperatures. It has been a common perception among composting researchers and practitioners that the minimum size of a pilot compost pile must be at least 19 to $38 \mathrm{~m}^{3}$ ( 25 to $50 \mathrm{cu} \mathrm{yd}$ ) in order to retain the heat (Hanif 1995).

Several researchers used feedback temperature control and heating systems in order to minimize the heat loss and were able to maintain selfheating induced thermophilic conditions (Cook, Bloom, and Halback 1994; Hogan, Miller, and Finstein 1989; Magalhaes et al. 1993). Small bench-scale remediation composting systems require much more precise design and operational control in order to be successful, compared with rather insensitive but more stable pilot-scale compost piles. 
The Waterways Experiment Station Adiabatic Composting System (WACS) II is a composting reactor with a sophisticated feedback temperature control and heating system. Compost Mix 7 was evaluated for the feasibility of treating soils contaminated with the explosives in actual composting environments using the WACS II system.

\section{Materials and Methods}

\section{Bench-scale reactor system}

The WACS II is a pseudo-adiabatic composter combined with instrumentation and automatic data collection (Figure 3 ). The composting reactor is a $14-\mathrm{L}$ polyvinyl chloride cylinder insulated to reduce conductive heat transfer. This reactor is placed into a Styrofoam box to further isolate the composter from ambient temperatures. This isolation eliminates heat loss so that heat can accumulate inside the reactor, raising the composting temperature. The resistance temperature probes (RTDs) were inserted into the center of the composting reactor as well as against the inside and outside of the cylinder wall. A proportional-integral-derivative feedback temperature control system used the two reactor wall RTD measurements to track the temperature differences. The temperature of air in the Styrofoam box is maintained at the same temperature of the inside reactor wall by passing preheated or cooled water through a radiator inside the box while a fan circulates the temperature-controlled air.

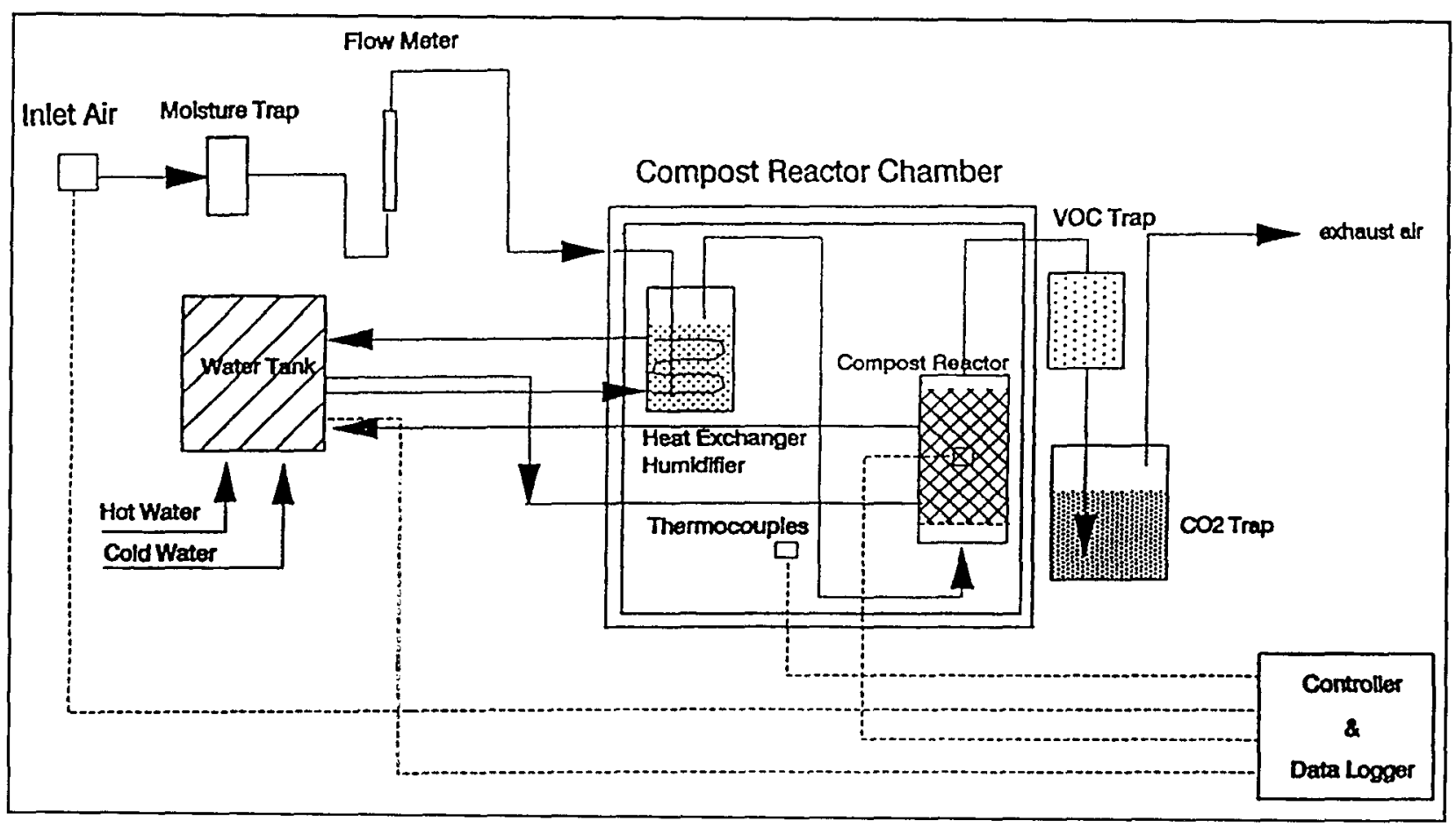

Figure 3. Schematic diagram of bench-scale batch compost reactor system 
Finally, preconditioned air is supplied to the reactor to maintain aerobic respiration and to reduce convective heat loss from the composting pile through the latent heat of vaporization. Air temperature is dynamically adjusted to the temperature at the core of the composting pile. Air is also humidified before entering the reactor. Aeration events occur every 1 in $10 \mathrm{~min}$ if the composting temperature is less than $55^{\circ} \mathrm{C}$ or continuously if the temperature is above $55^{\circ} \mathrm{C}$. Temperature readings were recorded every $2 \mathrm{~min}$ as well as total elapsed time for aeration events.

\section{University of Minnesota compost reactor system}

To evaluate the contaminant fate of TNT via radiolabeled method, the composting Mixture 4 was placed in a $20-\mathrm{L}$ composter that is $31 \mathrm{~cm}(1 \mathrm{ft})$ in diameter and $40 \mathrm{~cm}$ (16 in.) in height (Figure 4). Ambient air is pulled through the system by a laboratory vacuum at a pressure of 15-17 in. of mercury. The airflow is regulated with a flow meter. A gas-drying jar containing Baralyme granules was used to dry the air and to remove some $\mathrm{CO}_{2}$. The remaining $\mathrm{CO}_{2}$ is removed through a $3.8-\mathrm{L}$ (1-gal) jar of 1 molar of $\mathrm{KOH}$ solution. Passing it through a distilled water trap humidifies filtered air. The humidified air enters the bottom of the compost reactor and exits at the top. It is then condensed in a stainless steel tube coil that is cooled by a large fan. The condensed water is collected in a moisture

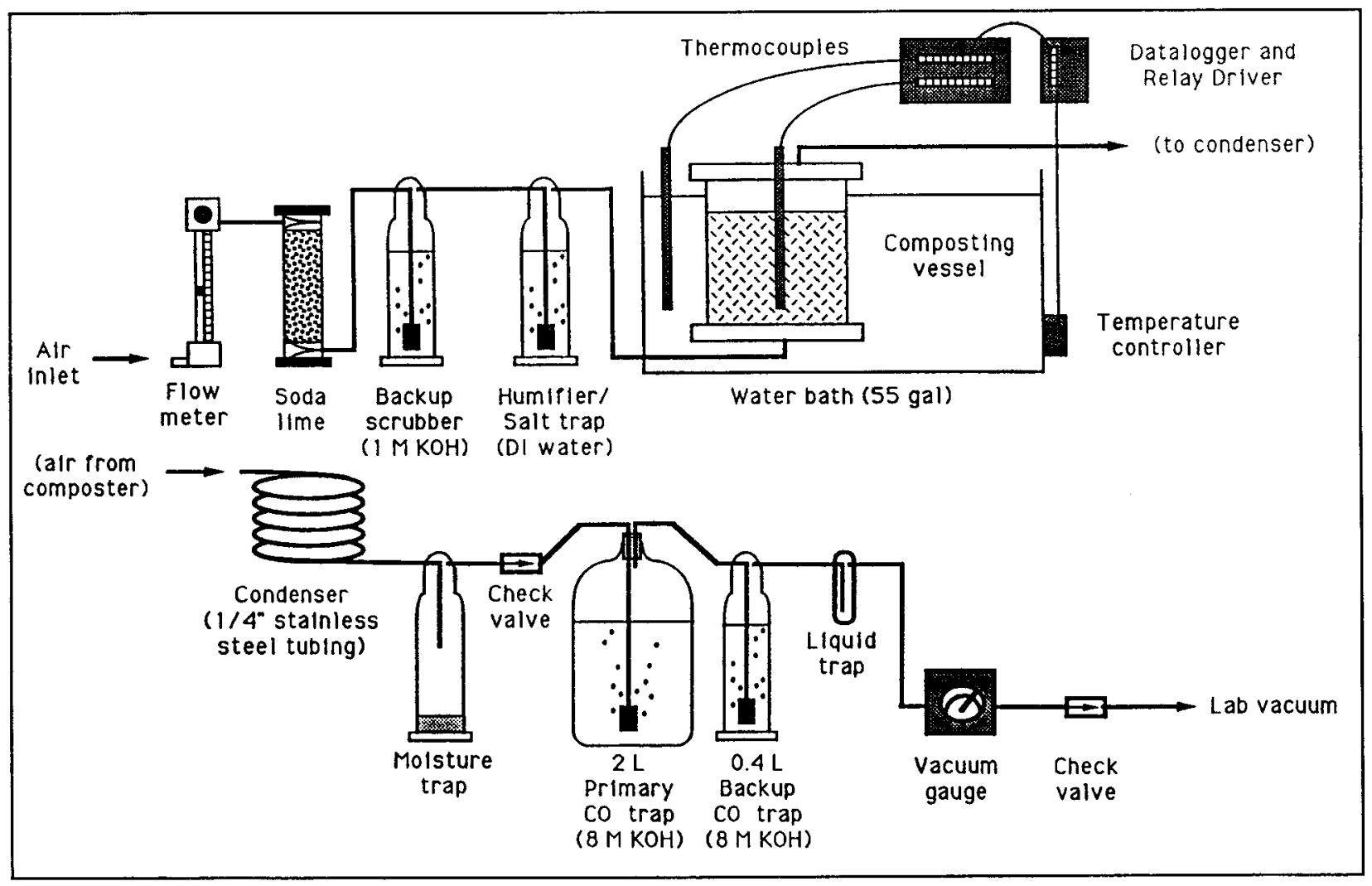

Figure 4. Schematic diagram of University of Minnesota compost reactor system (Cook, Bloom, and Halback 1994) 
trap while the air passes through an organic trap consisting of foam absorbers. The $\mathrm{CO}_{2}$ is removed from the air again in two $\mathrm{KOH}$ traps. The primary trap contains $1,800 \mathrm{ml}$ of the $\mathrm{KOH}$ solution. The secondary trap contains $400 \mathrm{ml}$ of $\mathrm{KOH}$. After $\mathrm{CO}_{2}$, organics, and moisture have been removed, the air passes through another moisture trap, then to the vacuum.

The reactor uses thermocouples to monitor the compost temperature. The reactor tracks temperature as well as microbial activity through $\mathrm{O}_{2}$ and $\mathrm{CO}_{2}$ traps in the exit airstream. Two thermocouples are used to display the temperature of the compost. One thermocouple is placed at the core of the reactor, and the other thermocouple is placed at the inside edge of the reactor. Temperatures were automatically logged.

\section{Compost mixing procedure}

The ingredients for Mixtures 3 (40-percent cow manure, 40-percent cornstalk, and 20-percent soil) and 4 (40-percent pig manure, 40 -percent cornstalk, and 20 -percent soil) were measured by volume, weighed, and mixed together in a 57-L (15-gal) twin-shell mixer. Table 5 shows the composition of Mixtures 3 and 4 used in the bench-scale system. Table 6 shows the composition of Mixture 4 used in the University of Minnesota compost system.

\begin{tabular}{|c|c|c|c|c|c|c|c|}
\hline $\begin{array}{l}\text { Mixture } \\
\text { Number }\end{array}$ & Ingredient & $\begin{array}{l}\text { Percent by } \\
\text { Volume }\end{array}$ & $\begin{array}{l}\text { Wet } \\
\text { Weight, } \mathrm{g}\end{array}$ & $\begin{array}{l}\text { Percent by } \\
\text { Wet Weight }\end{array}$ & $\begin{array}{l}\text { Percent } \\
\text { Moisture }\end{array}$ & $\begin{array}{l}\text { Dry Weight } \\
\mathbf{g}\end{array}$ & $\begin{array}{l}\text { Percent by } \\
\text { Dry Weight }\end{array}$ \\
\hline \multirow[t]{4}{*}{3} & Cow manure & 40 & $2,119.68$ & 35 & 18 & 381.54 & 16 \\
\hline & Cornstalks & 40 & 174.33 & 3 & 92 & 160.38 & 7 \\
\hline & Soil & 20 & $2,884.83$ & 49 & 66 & $1,904.00$ & 77 \\
\hline & Water & $=$ & 750 & 13 & - & - & - \\
\hline \multirow[t]{4}{*}{4} & Swine manure & 40 & $2,118.56$ & 37 & 28 & 593.20 & 22 \\
\hline & Cornstalks & 40 & 173.72 & 3 & 92 & 159.82 & 6 \\
\hline & Soil & 20 & $2,879.55$ & 51 & 66 & $1,900.50$ & 72 \\
\hline & Water & - & 500 & 9 & - & $1-$ & - \\
\hline
\end{tabular}

\section{Table 6}

Radiolabeled - Compost Composition for Mixture 4

\begin{tabular}{|l|l|l|l|l|}
\hline $\begin{array}{l}\text { Mixture } \\
\text { Number }\end{array}$ & Ingredient & $\begin{array}{l}\text { Percent by } \\
\text { Volume }\end{array}$ & Dry Weight, g & $\begin{array}{l}\text { Percent by Dry } \\
\text { Weight }\end{array}$ \\
\hline 4 & \multicolumn{3}{|c|}{ IAAP Line 1 Impoundment Soil } \\
\cline { 2 - 5 } & Pig manure & 40 & 0.81 & 12 \\
\cline { 2 - 5 } & Cornstalks & 40 & 0.37 & 5 \\
\cline { 2 - 5 } & Soil & 20 & 5.59 & 83 \\
\hline & \multicolumn{4}{|c|}{ WES Reference Soil } \\
\hline
\end{tabular}




\section{Results and Discussion}

\section{Bench-scale reactor system}

Figure 5 compares TKN, pH, moisture content, TVS, and $\mathrm{C} / \mathrm{N}$ values for Mixtures 3 and 4 . The TVSs decreased approximately 22 percent for both mixtures. The TKN values showed the most significant differences between the two mixes. The TKN values increased in the cow mixture; however, the fluctuation was probably due to sampling error, so the concentration probably remained approximately constant. Meanwhile, the TKN concentration declined more than 50 percent in the pig mixture. The reduction in total nitrogen was expected to be caused by ammonia- $\mathrm{N}$ volatilization as well as nitrification. The moisture content remained approximately constant for the cow mixture ranging from 45.8 to 47.8 percent during the 30-day compost run, whereas the moisture content decreased from 37.6 to 26.1 , indicating an enthalpy change in the system for pig

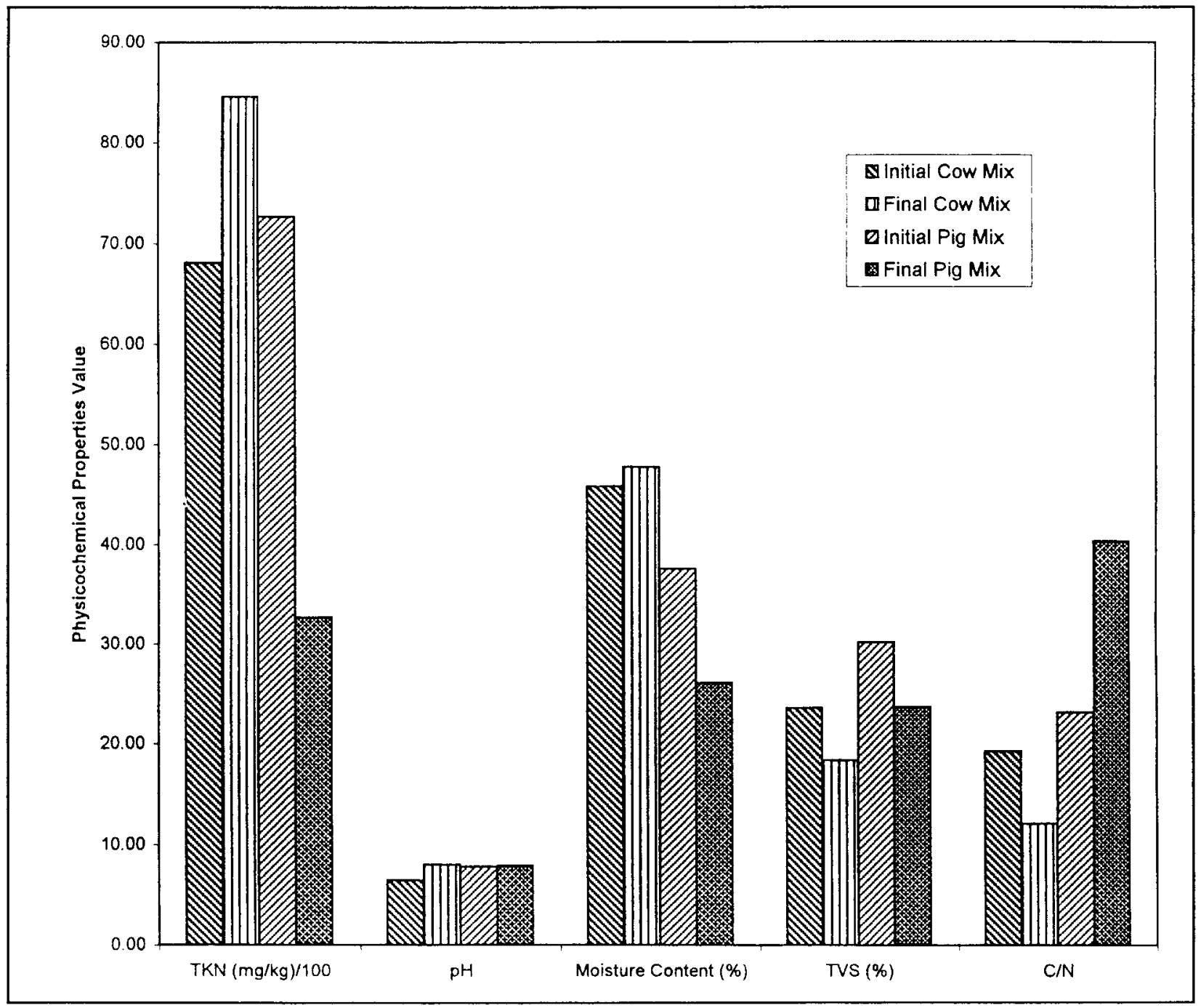

Figure 5. Physicochemical properties for Mixtures 3 and 4 
manure. The $\mathrm{pH}$ for both mixtures remained within exceptable ranges for microbial activity. Kayhanian and Tchobanoglous (1992) state that the initial $\mathrm{pH}$ range for composting is 5 to 7 , raises to approximately 8.5 as the compost reaches thermophilic temperatures, and settles to a $\mathrm{pH}$ of 7 to 8 in mature compost. The opposite trends in $\mathrm{C} / \mathrm{N}$ ratio occurred between the two mixes. A decrease in $\mathrm{C} / \mathrm{N}$ ratio occurs in the cow manure mixture because the TVS decreased while the TKN value remained approximately constant. Meanwhile, the $\mathrm{C} / \mathrm{N}$ ratio increased in the pig manure mixture, suggesting that the nitrogen levels decreased at a faster pace than the carbon degradation process.

Figures 6 through 8 show average core temperature as well as the overall temperature profile and aeration data for Mixture 3. Core temperature profile, Figure 6, for the cow manure compost displays the average core temperature profile for 30 days. The maximum and minimum temperatures for each day are also displayed as Y error bars. Due to complications in the self-heating apparatus, the temperature controller was turned off initially for 1 day and subsequently for 8 additional days. The composting piles remained mesophilic for the first 16 days. The temperature did increase to $40{ }^{\circ} \mathrm{C}$ ranges for the next 3 days. The temperature then plummeted to under $30^{\circ} \mathrm{C}$ for the rest of the run. These temperatures would allow ammonia to remain as $\mathrm{NH}_{3}$. Figure 7 displays the composting temperature profiles of the core, inside wall, and outside wall temperatures. The core composting temperature was slightly higher than the wall temperature, showing radial heat loss through the reactor. The feedback temperature control system maintained the outside wall temperature and

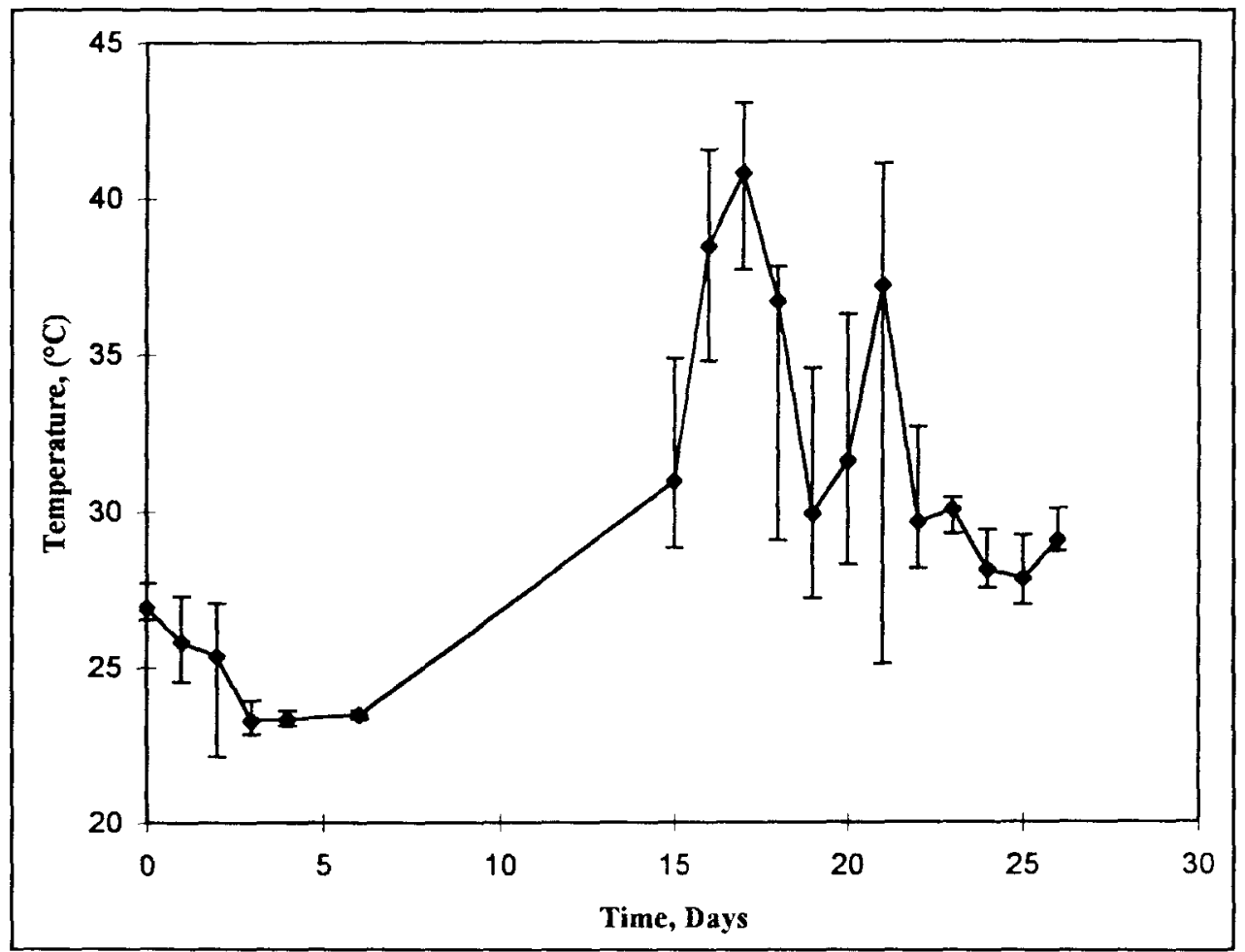

Figure 6. Cow mixture core temperature profile 


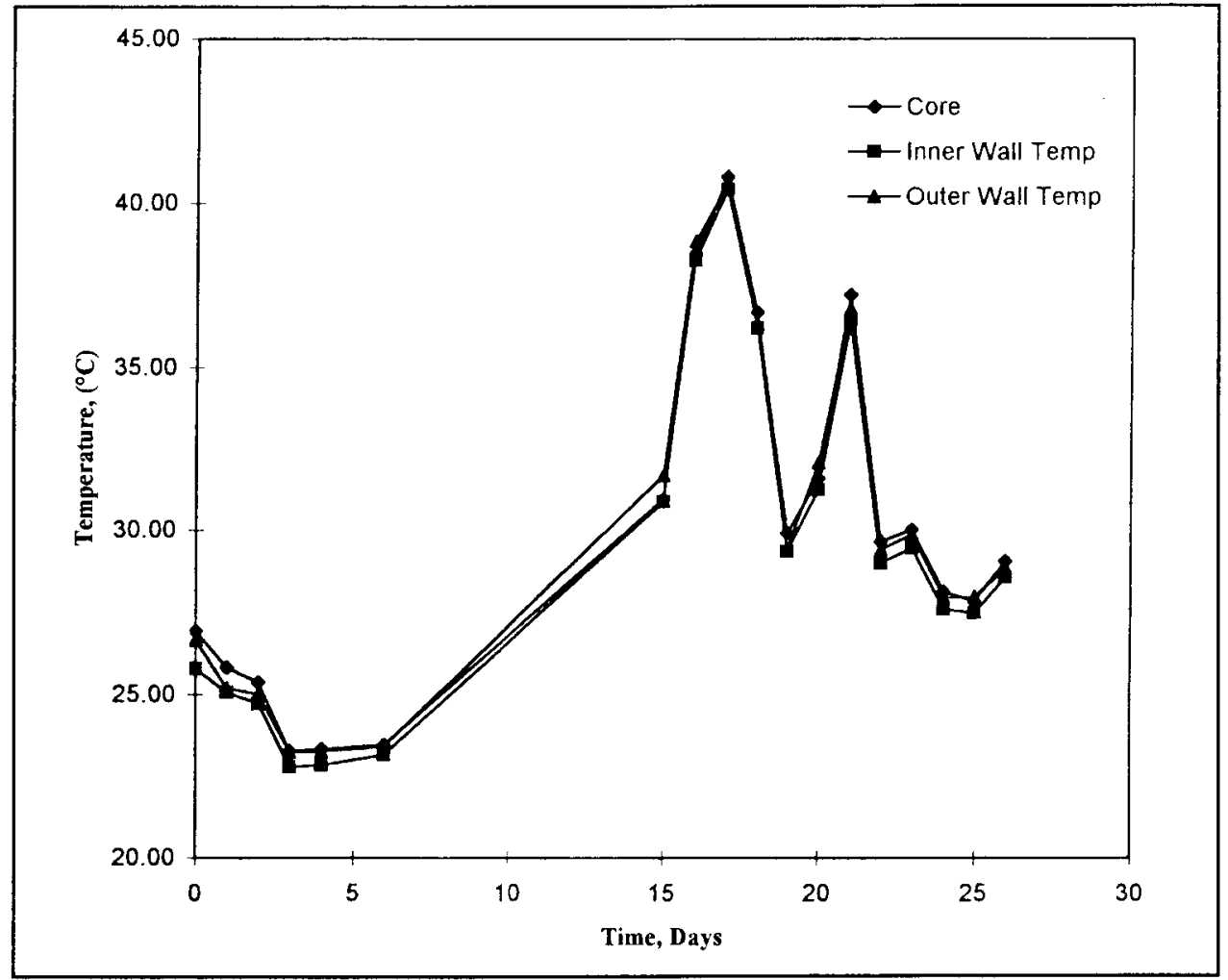

Figure 7. Cow mixture overall process temperature profile

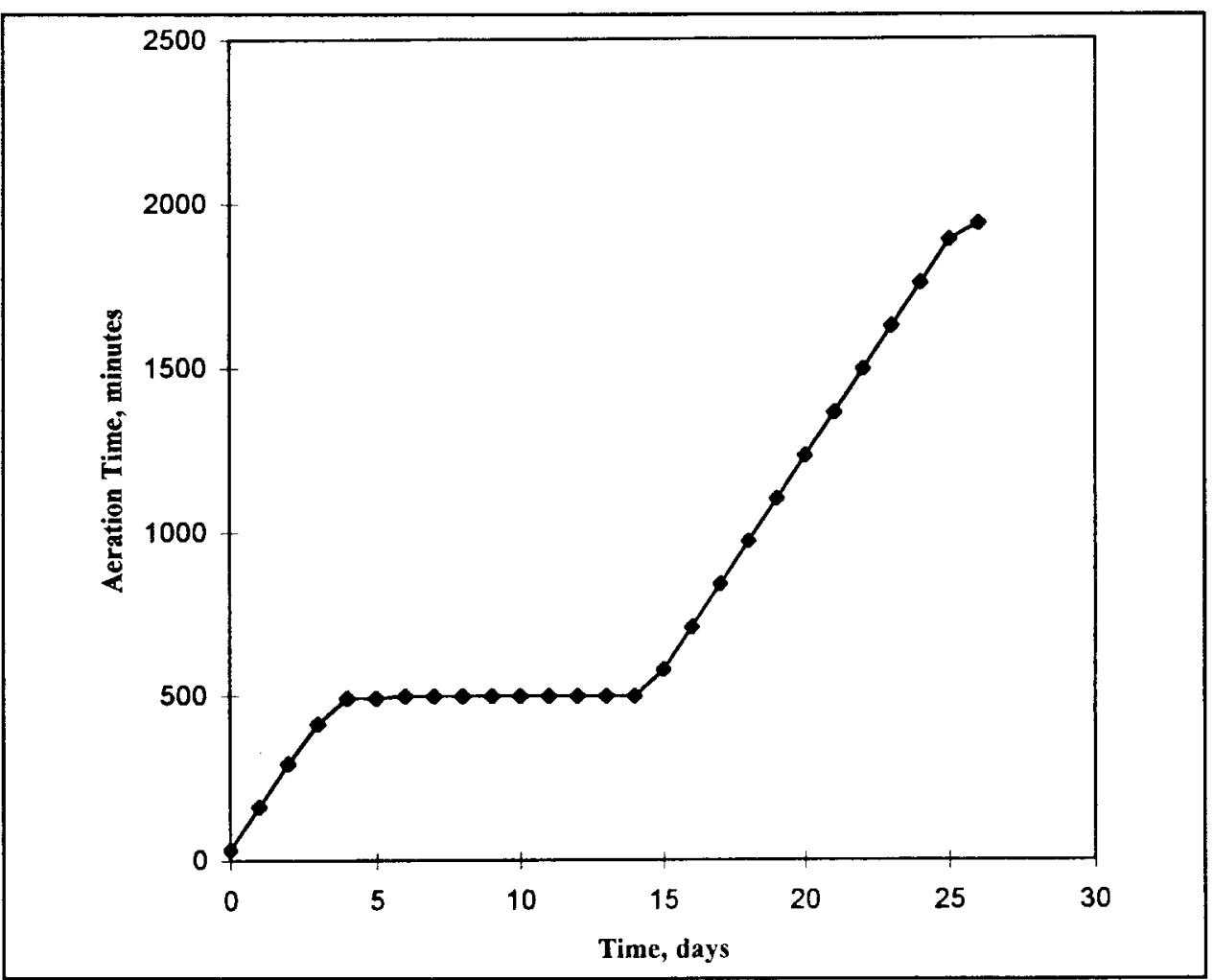

Figure 8. Cow mixture cumulative aeration 
inside wall temperature perfectly, ensuring adiabatic conditions. Figure 8 shows the cumulative aeration minutes. During Days 6 through 15 , no oxygen was added to the system. These anaerobic conditions may have had effect on the TKN values by producing a significant amount of nitric acid. Adding air to the system on Day 16 may have allowed some rapid depletion of carbon, increasing the temperature until the readily available carbon was exhausted lowering the temperature. The overall accumulated air, Figure 8 , was $1,936 \mathrm{~min}$ at $3.78 \mathrm{~L} / \mathrm{min}$. Air was exchanged 522 times throughout this run. Haug (1993) estimated that a yard waste composting pile with 80-percent TVS and 50-percent degradability would require 1,510 exchanges. Since the degradability rate of cow mixture was 4 percent and the flow rate was higher, the number of exchanges for this composting run should be lower. The overall aeration for this composting run was $0.53 \mathrm{~m}^{3} / \mathrm{kg}$ VS-day.

Figures 9 through 12 display the average core temperature as well as the overall temperature profile and aeration data for the pig mixtures (Mixture 4). Figure 9 shows the average core temperature profile of the pig compost for 30 days. The maximum and minimum temperatures for each day are also displayed as $\mathrm{Y}$ error bars. The composting piles reached a thermophilic temperature range within the first $24 \mathrm{hr}$; however, the failure in the temperature control system limited the heat accumulated, causing a decline in temperature. The temperamental behavior of the temperature control system continually retarded the self-heating capacity of the compost until the readily available carbon diminished after Day 20 . Even

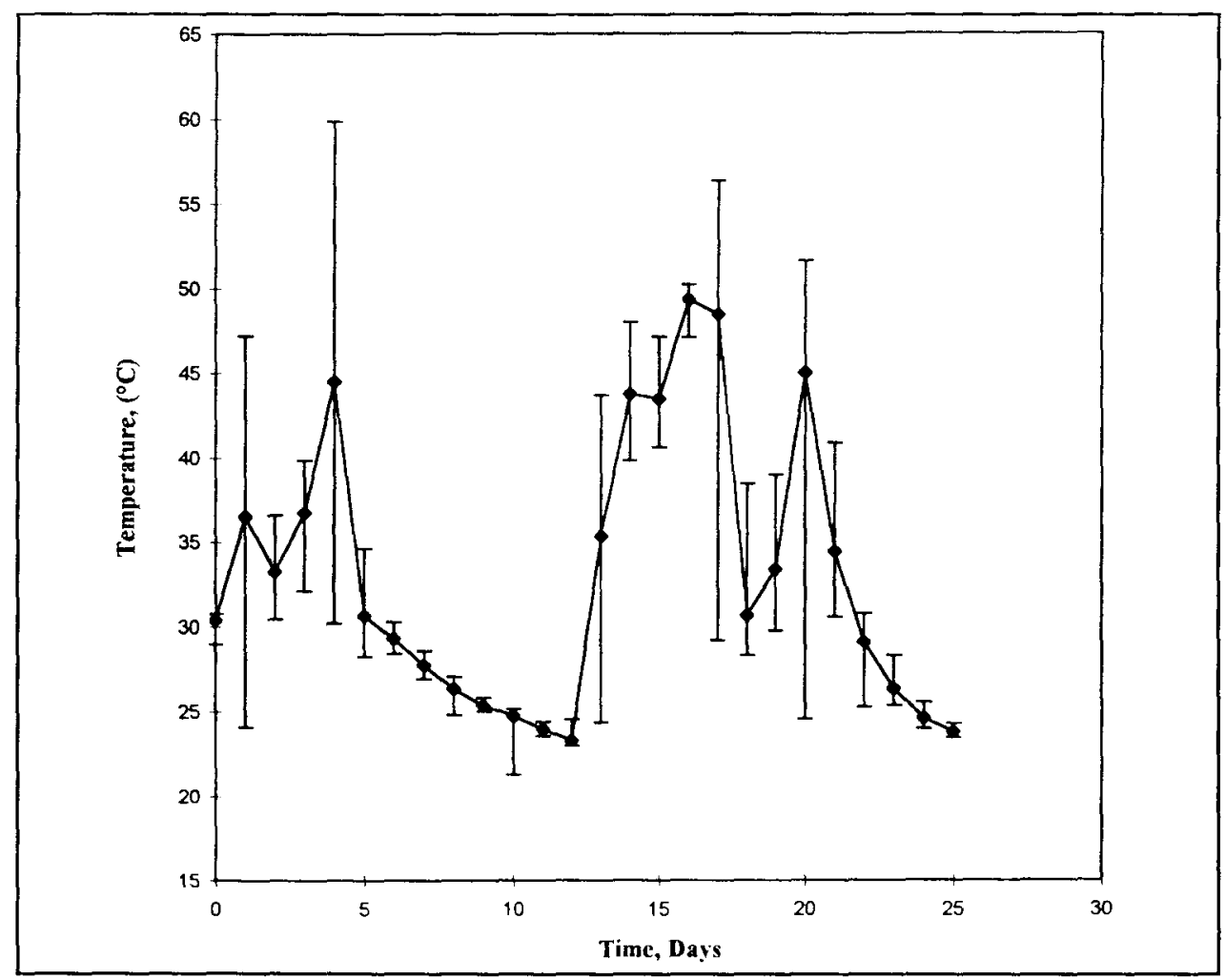

Figure 9. Pig mixture core temperature profile 


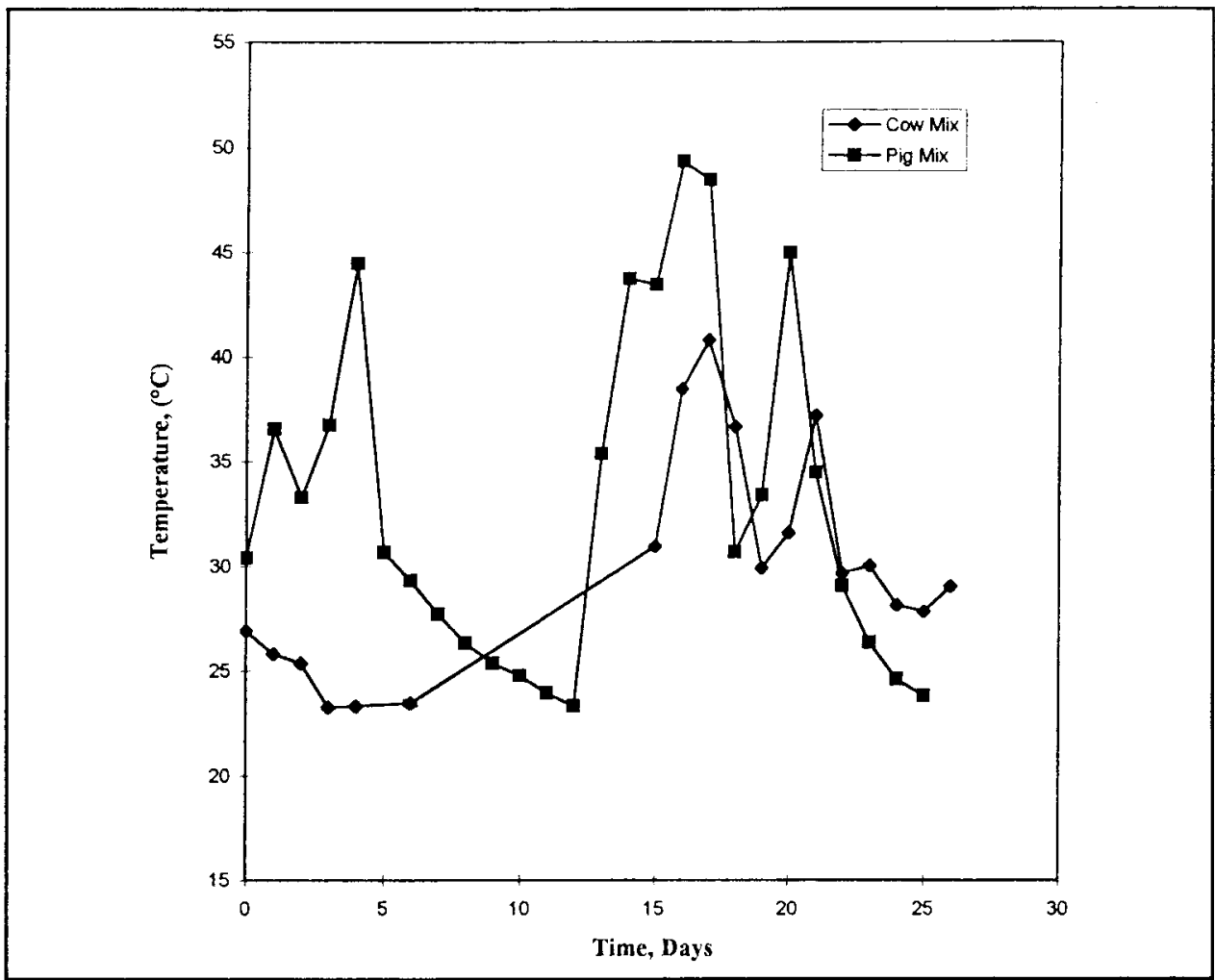

Figure 10. Comparison of cow and pig mixture core temperature

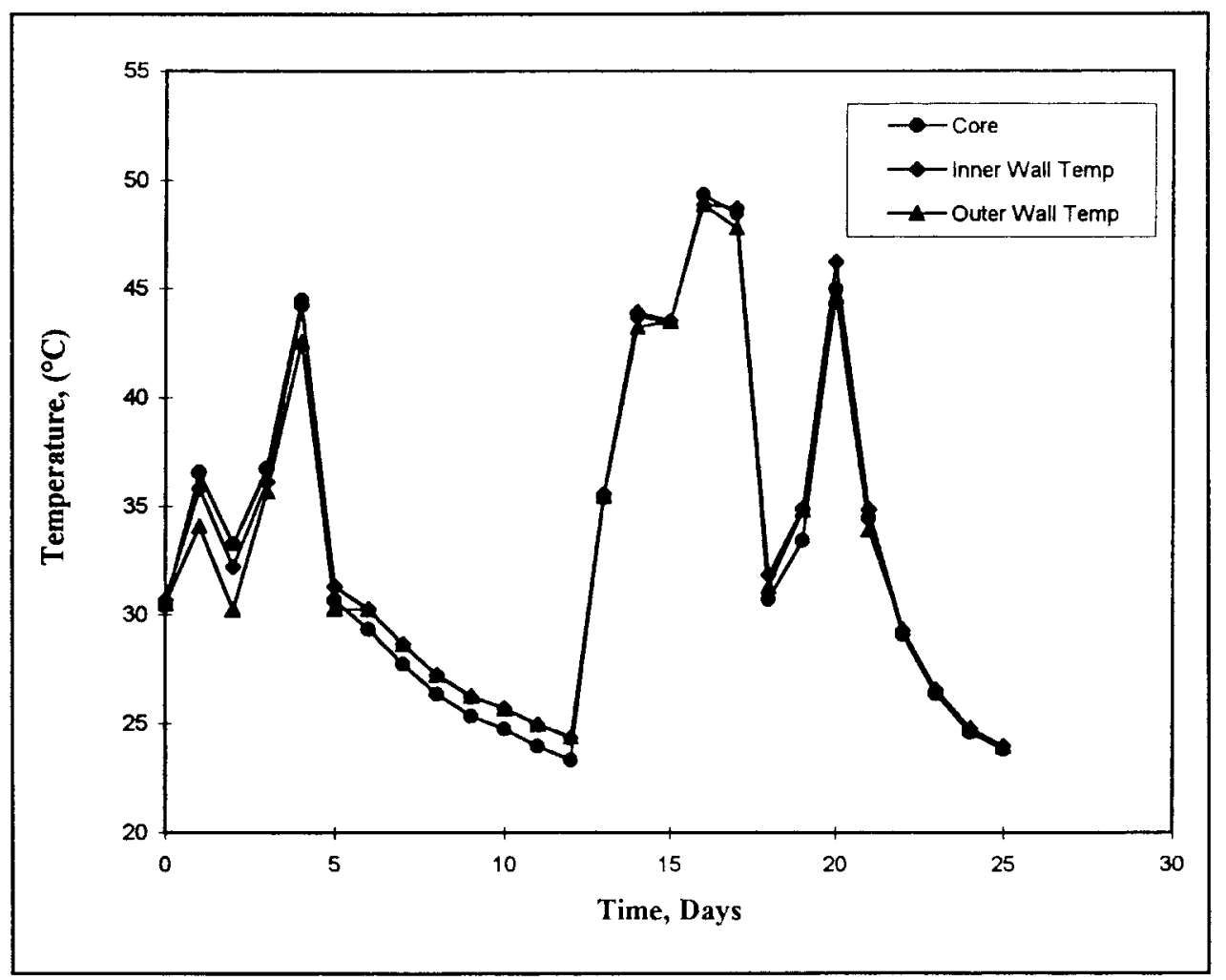

Figure 11. Pig mixture overall process temperature profile 


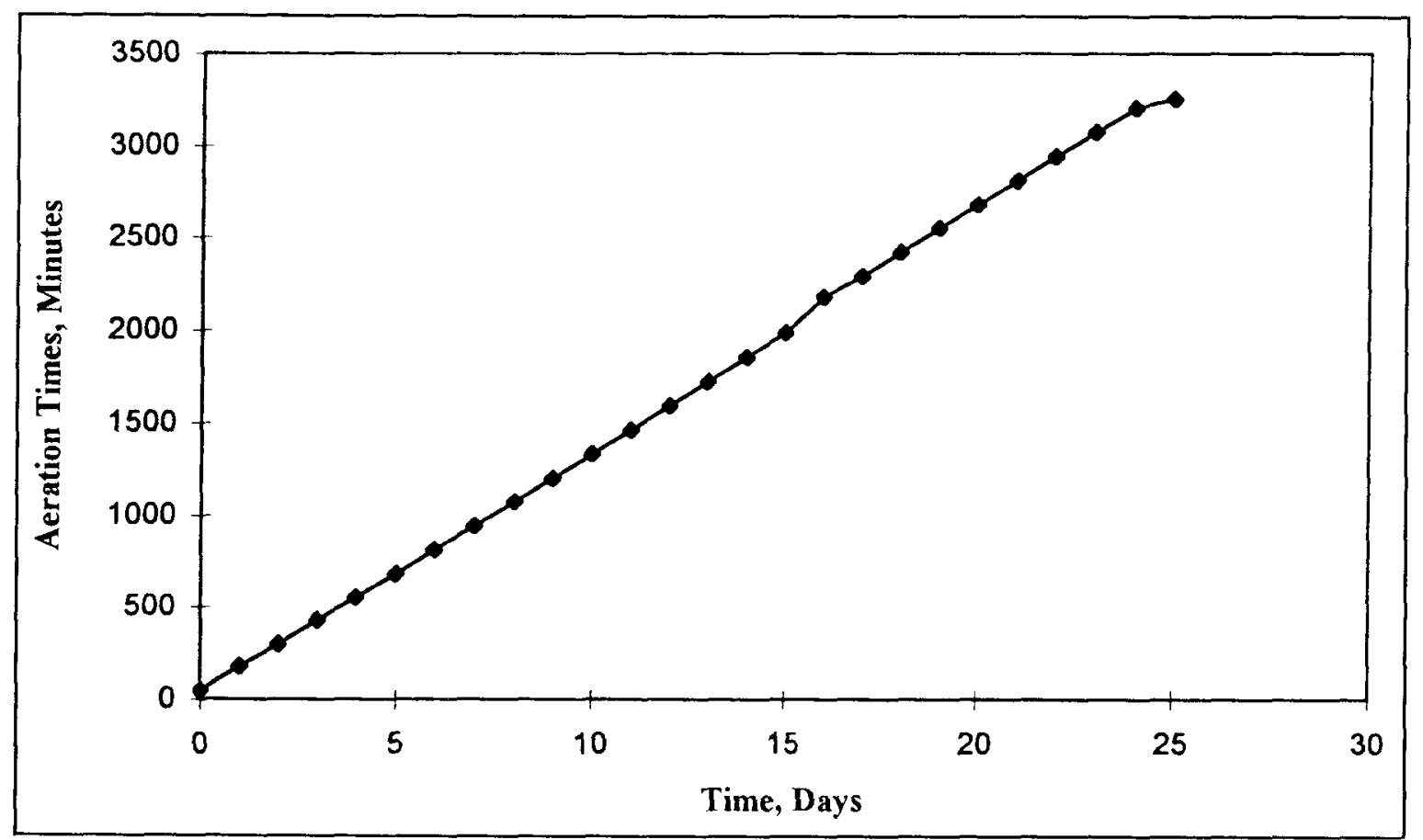

Figure 12. Pig mixture cumulative aeration

though the temperature fluctuated during this experiment, the temperature profile achieves the goals of field-scale composting by accumulating heat, raising the temperature of the pile, and reducing temperatures after several days. This compost run conformed to the USEPA regulations that the compost temperature must maintain a temperature of $40{ }^{\circ} \mathrm{C}$ for at least 5 days and reach a temperature of $55^{\circ} \mathrm{C}$ for a 4 -hr period. The compost pile reached thermophilic temperatures for at least 8 days. Figure $10 \mathrm{com}-$ pares the average core temperature for the cow and pig mixtures. Figure 10 shows the compost temperature of pig mixture extended that of the cow mixture. Figure 11 shows the overall temperature profiles for the pig manure, and it displays similar trends to that of the cow manure compost. Again, the core composting temperature was higher than the wall temperature, showing radial heat loss through the reactor. Figure 12 shows cumulative aeration for this compost run. Day 16 had the highest aeration using $193 \mathrm{~min}$ of air at a rate of $3.78 \mathrm{~L} / \mathrm{min}$. The number of aeration minutes corresponded well to the temperature profile. The overall accumulated air was 3,253 min. Air was exchanged 878 times throughout this run. The overall aeration for this composting run was $0.65 \mathrm{~m}^{3} / \mathrm{kg}$ VS-day.

Figure 13 shows the degradation of HMX and RDX concentrations. TNT, 4A-DNT, and 2A-DNT concentrations were undetected in both the cow and pig mixtures (Table 7). The cow mixture also showed no significant concentration reduction in HMX and RDX. The lack of reduction of explosive concentration in the cow mixture was expected since there was no significant heat accumulation in the mix and a limited supply of air. WES has used cow manure in other composting mixtures and also seen no 


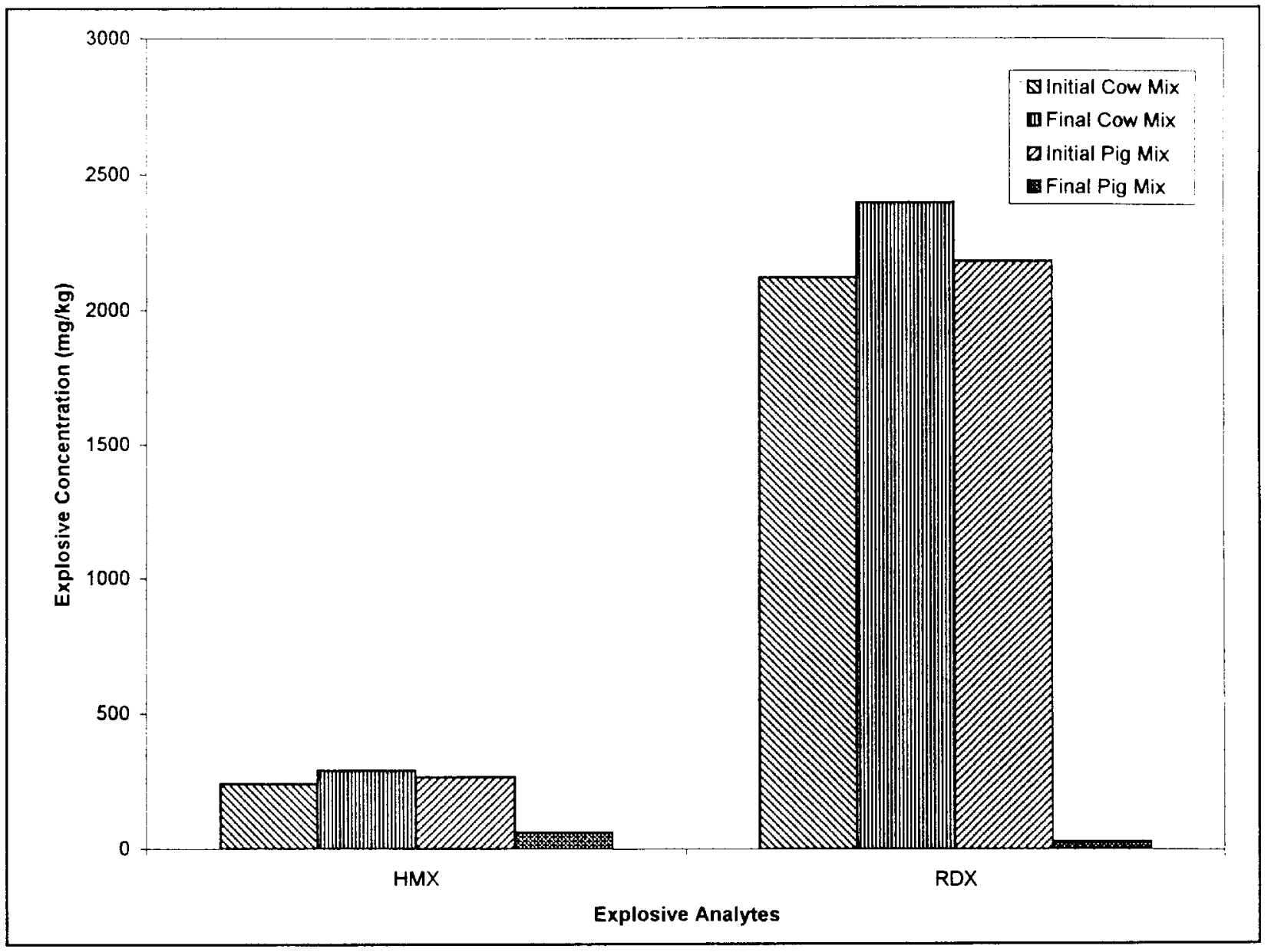

Figure 13. Average explosive analysis results for Mixtures 3 and 4

\section{Table 7}

Bench-Scale - Explosive Analysis for Mixtures 3 and 4

\begin{tabular}{|c|c|c|c|c|c|c|}
\hline \multirow{2}{*}{$\begin{array}{l}\text { Mixture } \\
\text { Number }\end{array}$} & \multirow[b]{2}{*}{ Sample No. } & \multicolumn{5}{|c|}{ Explosive Concentrations, mg/kg } \\
\hline & & TNT & RDX & HMX & 2A-DNT & 4A-DNT \\
\hline \multirow{5}{*}{3} & Day 0 & $19.3 \mathrm{~J}$ & 2,120 & 240 & $\mathrm{BDL}$ & 8.00 \\
\hline & Day 30 , Replicate 1 & $15.8 \mathrm{~J}$ & 2,480 & 288 & 12.4 & 8.09 \\
\hline & Day 30 , Replicate 2 & $22.0 \mathrm{~J}$ & 2,600 & 321 & 14.6 & 9.77 \\
\hline & Day 30 , Replicate 3 & $19.7 \mathrm{~J}$ & 2,110 & 260 & 13.2 & 9.31 \\
\hline & Average & $19.2 \mathrm{~J}$ & 2,397 & 290 & 13.4 & 9.06 \\
\hline \multirow{5}{*}{4} & Day 0 & $15.2 \mathrm{~J}$ & 2,180 & 266 & $\mathrm{BDL}$ & 5.10 \\
\hline & Day 30, Replicate 1 & $14.4 \mathrm{~J}$ & 23.6 & 49.9 & 11.0 & 6.43 \\
\hline & Day 30 , Replicate 2 & 25.9 & 39.0 & 81.4 & 13.1 & 8.11 \\
\hline & Day 30 , Replicate 3 & $15.9 \mathrm{~J}$ & 23.7 & 57.5 & 12.5 & 6.08 \\
\hline & Average & $18.7 \mathrm{~J}$ & 28.8 & 62.9 & 12.2 & 6.87 \\
\hline \multirow{5}{*}{ Soil } & Replicate 1 & $20.4 \mathrm{~J}$ & 973 & 138 & 11.5 & 5.50 \\
\hline & Replicate 2 & 58.5 & 4,290 & 510 & 40.6 & 19.2 \\
\hline & Replicate 3 & 44.0 & 3,360 & 423 & 31.4 & 15.6 \\
\hline & Replicate 4 & 28.6 & 2,560 & 316 & 23.7 & 12.4 \\
\hline & Average & 37.9 & 2,796 & 347 & 26.8 & 13.2 \\
\hline
\end{tabular}


reduction in HMX (Preston, Seiden, and Ro 1997). However, the pig manure mixture showed significant reduction for both HMX and RDX concentrations. The initial and final values for $\mathrm{HMX}$ was 266 and $63 \mathrm{mg} / \mathrm{kg}$, respectively (77-percent reduction). RDX concentration was diminished by 98.7 percent.

\section{University of Minnesota compost reactor system}

Based on the bench-scale study results, WES determined the best compost mix for degrading explosives in IAAP soil was Mixture 4. To ensure that the mix was acceptable, WES had to prove the pig compost mixture would rise to thermophilic temperatures. In addition, WES wanted to identify if any temperature differences occurred using IAAP Former Line 1 Impoundment soil and WES' reference soil.

The experiment was to compare elevation in temperature between explosives-contaminated soil and WES' reference soil. IAAP Former Line 1 Impoundment soil was used in this first experiment as well as WES' reference soil as the blank. This experiment lasted 30 days. The dry weights for this mixture had about 2.5 times more soil than the composts prepared in the previous study. This corresponds to about 84 percent by dry weight for the mixes.

Figure 14 compares $\mathrm{O}_{2}$ and $\mathrm{CO}_{2}$ headspace rates for the TNTcontaminated soil and the WES' reference soil. The decline in oxygen corresponds well with the increase production rate of $\mathrm{CO}_{2}$ for both soils. In addition, the figure shows that most of the biological activity ceases after 15 days of composting. Figure 14 also shows that the WES' reference soil produced a higher amount of $\mathrm{CO}_{2}$. However, both soils show a different rate of oxygen uptake and $\mathrm{CO}_{2}$ mineralized. Figure 14 shows that the microorganism within composts for the TNT soil and WES' reference soil has an increase in consumed oxygen beginning at Day 4 and Day 8 , respectively. Similar patterns are displayed for the rate of $\mathrm{CO}_{2}$ production. Figure 15 shows the temperature profiles of each soil type having the same trends; however the reference soil maintained higher temperatures once $50{ }^{\circ} \mathrm{C}$ was reached.

Figure 16 shows the initial and final concentrations of TNT in milligrams of TNT per kilogram of compost $(\mathrm{mg} / \mathrm{kg})$. The initial concentration of TNT of $513 \mathrm{mg} / \mathrm{kg}$ reduced to $14 \mathrm{mg} / \mathrm{kg}$ (97-percent reduction). The half-life of TNT degradation for this mixture was 5.77 days.

The second experiment compared composts with and without radiolabeled TNT. The components and dry weights for this run are shown in Table 6 . The total weights of both mixers are approximately equal. The unlabeled compost weighed in at $3.40 \mathrm{~kg}$ and the labeled compost at $3.41 \mathrm{~kg}$. The soil comprised about 85 percent of the dry weight. 


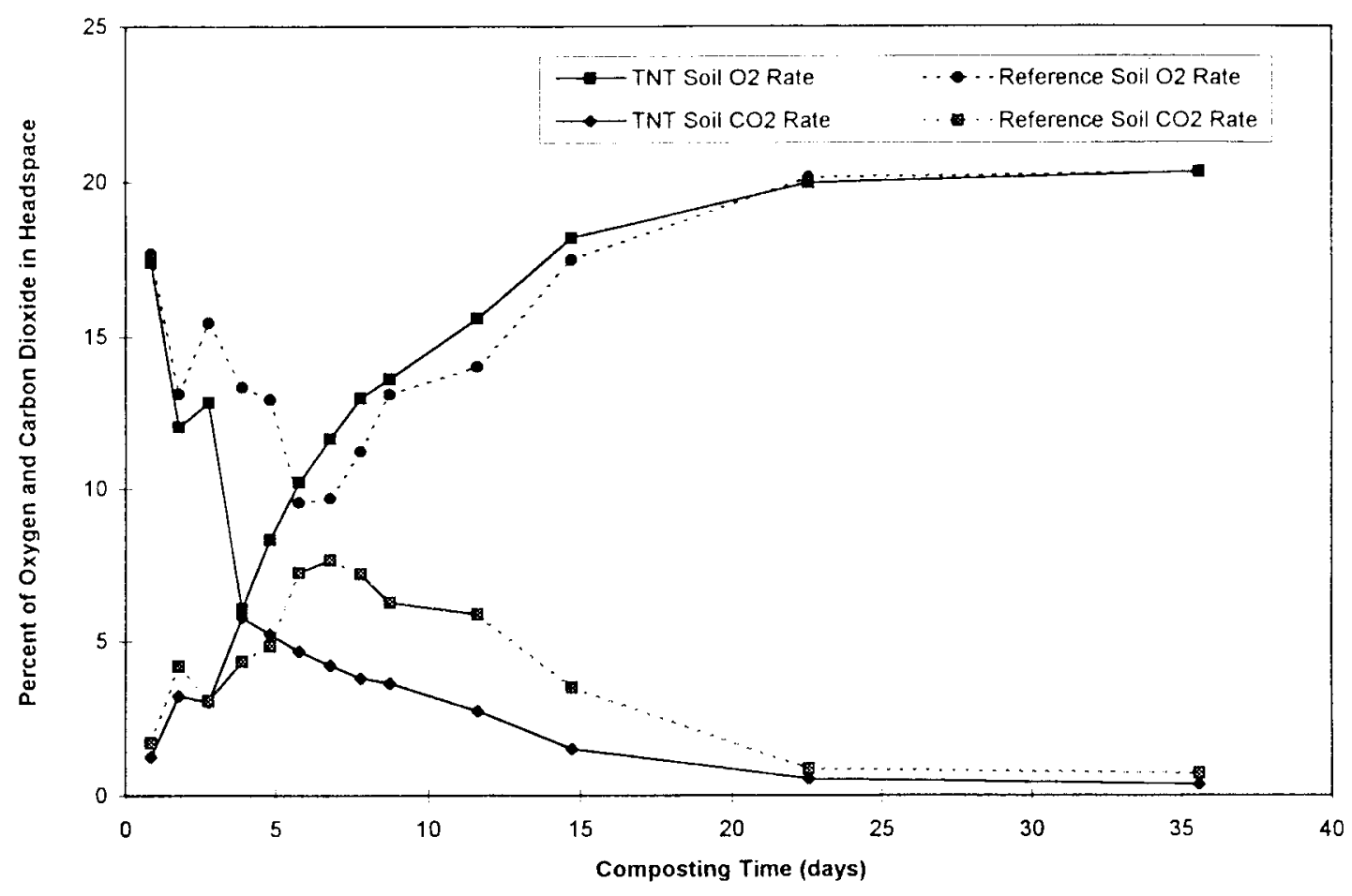

Figure 14. University of Minnesota $\mathrm{O}_{2}$ and $\mathrm{CO}_{2}$ headspace rates

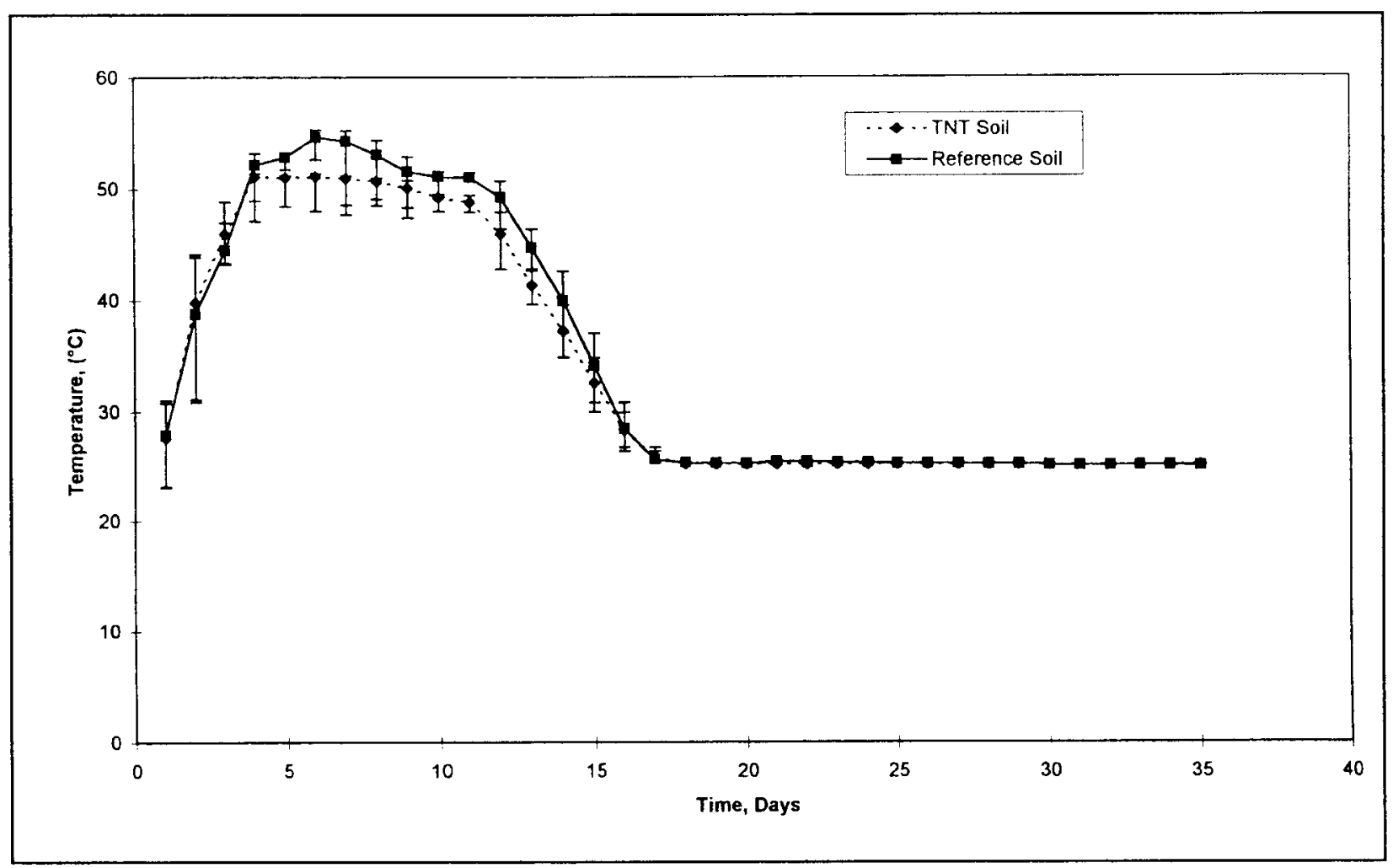

Figure 15. University of Minnesota core temperature profile 


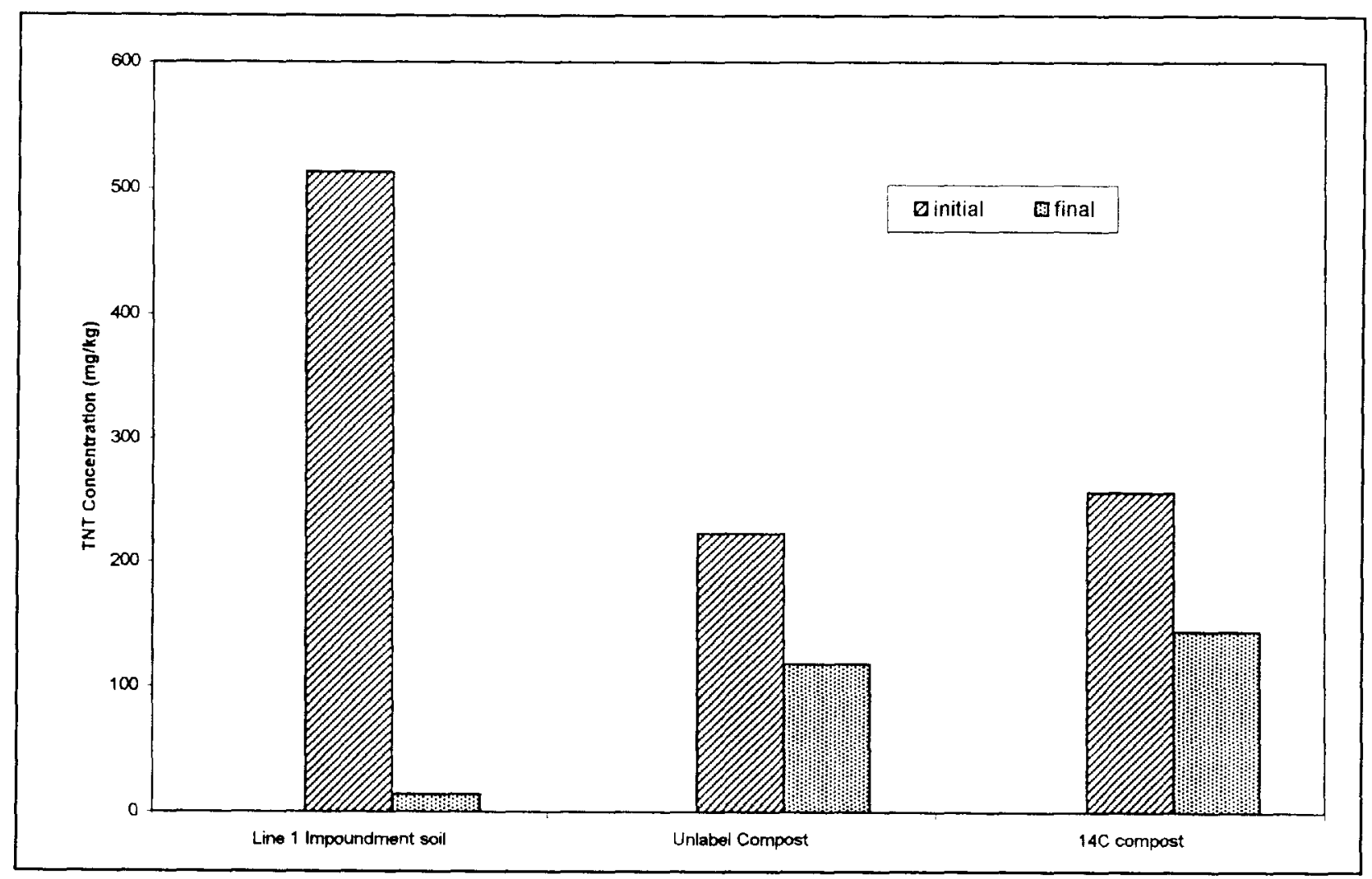

Figure 16. University of Minnesota initial and final TNT concentration

Figure 17 compares $\mathrm{O}_{2}$ and $\mathrm{CO}_{2}$ headspace rates for the unlabeled and labeled TNT-contaminated soil. The decline in oxygen corresponds well with the increase production rate of $\mathrm{CO}_{2}$ for both soils. Figure 17 also shows that most of the biological activity ceases after 15 days of composting. Figure 18 shows the temperature profiles of each soil type having the same trends. Figures 17 and 18 show little difference in the unlabeled and labeled TNT respiration rate and temperature profile, respectively.

Figure 16 also shows the initial and final concentrations of unlabeled and labeled TNT. Radiolabeled and unlabeled TNT concentrations were reduced by 44 and 47 percent, respectively. 


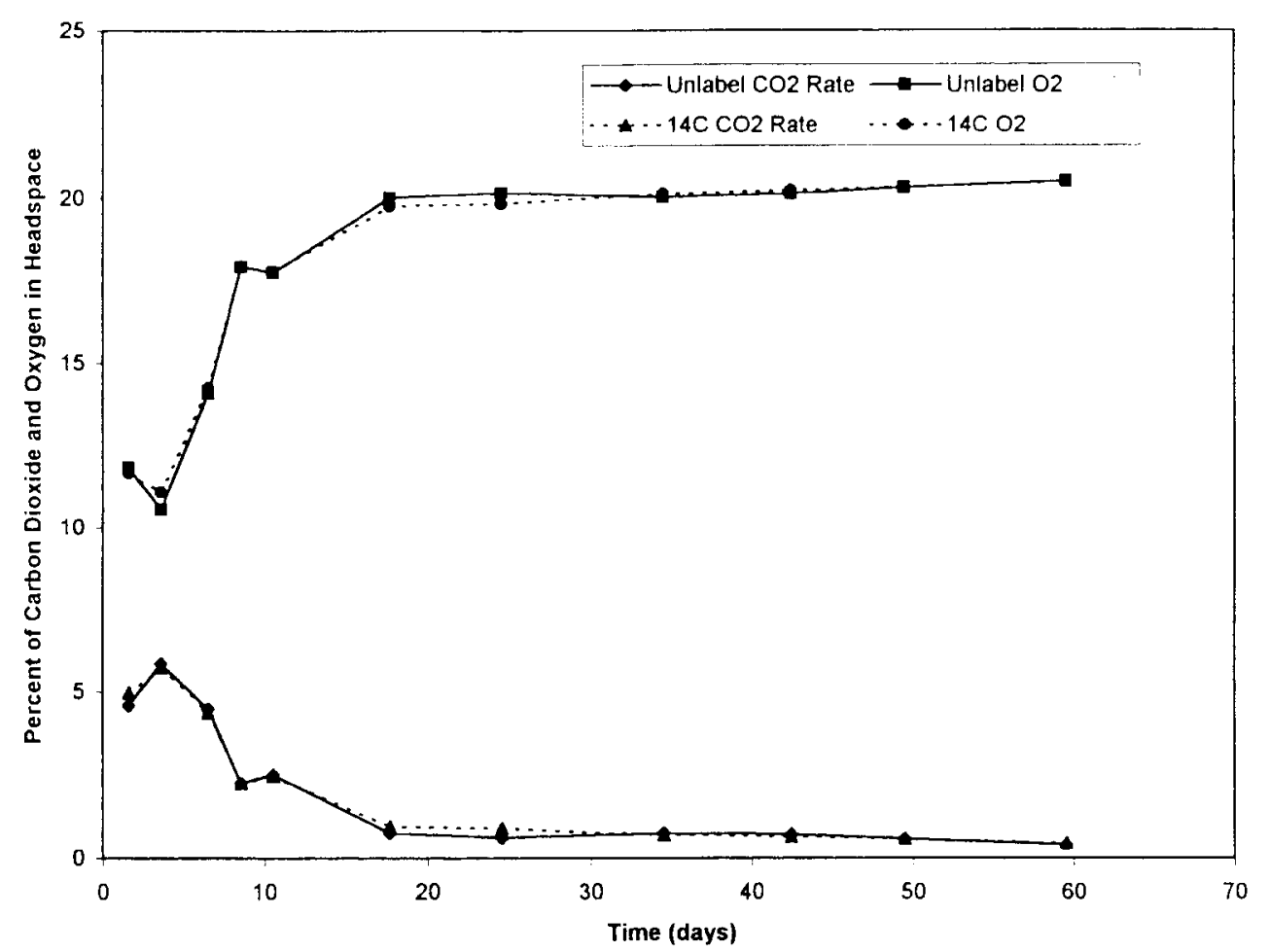

Figure 17. Radiolabeled $\mathrm{O}_{2}$ and $\mathrm{CO}_{2}$ headspace rates

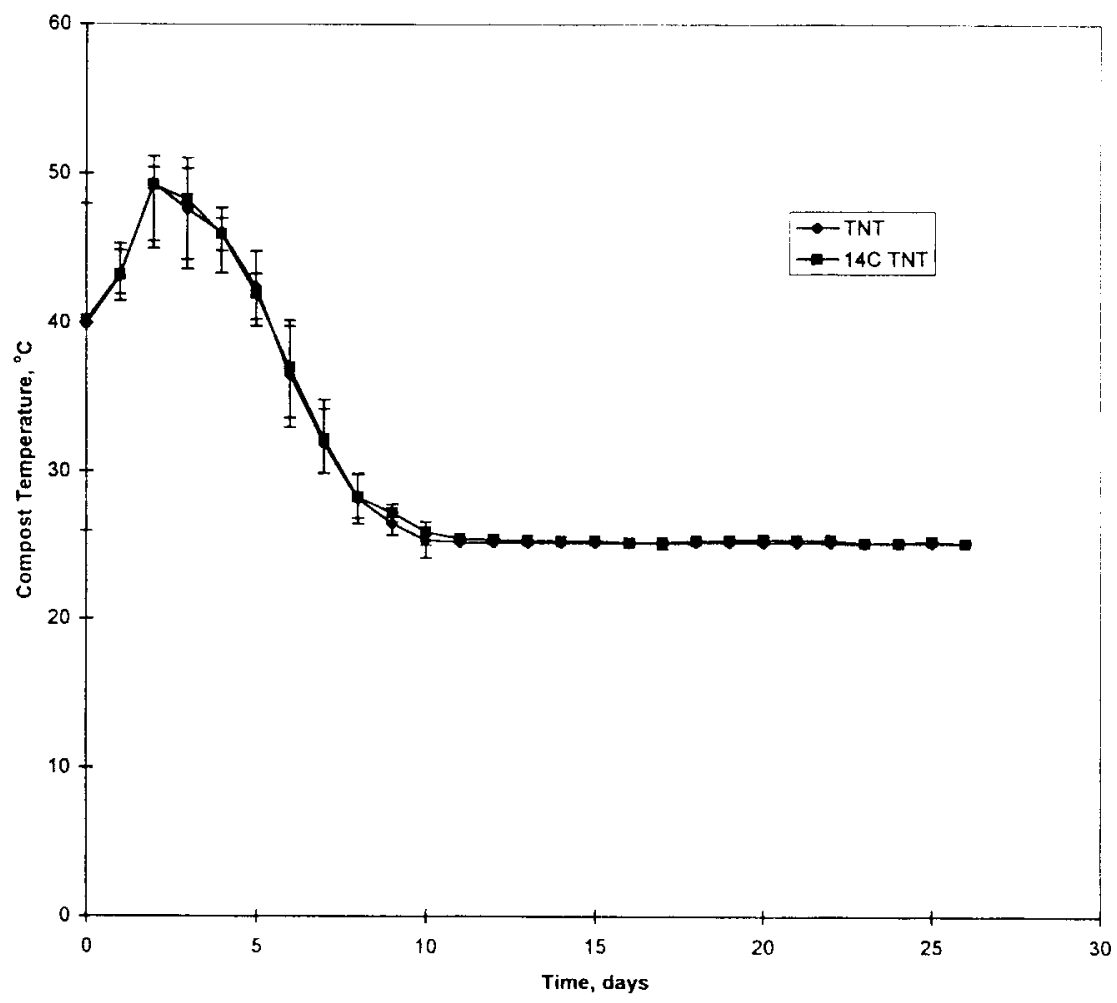

Figure 18. Radiolabeled core temperature profile 


\section{Conclusions and Recommendations}

\section{Conclusions}

Mixtures or various combinations of amendments and bulking agents were evaluated for composting using the respirometer as a screening tool. The bench-scale composting with the compost mixture selected from the respirometry was used to test the effectiveness of explosive-compound removal in actual composting environments.

Based on the results of the respirometric, bench-scale, and pilot-scale compost, the following is concluded:

a. The locally available amendments were cow manure and pig manure. The locally available bulking agents were sawdust, cornstalk, and wood chips.

b. Of eight compost mixes used in the respirometric study, Mix 3 (40percent cow manure, 40 -percent cornstalk, and 20-percent soil) and Mix 4 (40-percent pig manure, 40-percent cornstalk, and 20-percent soil) were ranked the highest.

c. Although Mix 6 was effective in removing explosives from the respirometric study at $40^{\circ} \mathrm{C}, \mathrm{SBR}$ and the maximum OURs of Mixtures 3 and 4 were the highest among the eight mixtures, respectively. Therefore, Mixtures 3 and 4 were selected for subsequent bench-scale compost study.

$d$. The bench-scale composting study had an overall average rate of aeration of 0.53 and $0.65 \mathrm{~m}^{3}$ air $/ \mathrm{kg}$ VS-day for Mixtures 3 and 4 , respectively. The moisture content remained approximately constant ranging from 45.8 to 47.8 percent and decreased for Mixture 4 ranging from 37.6 to 26.1 percent. 
$e$. TKN values continuously decreased over the entire composting period. Several reasons may be volatilization loss of ammonia- $\mathrm{N}$ during initial composting phase and nitrification during final phase of composting. The decrease in TKN during the later stage of composting resulted in increase in $\mathrm{C} / \mathrm{N}$ ratio from 30.7 on Day 15 to 34.7 on Day 35.

$f$. The majority of the explosive and transformation product concentrations using the WACS II system was reduced within the first 15 days of composting. Compost Mix 3 did not reduce the HMX concentration compared with the compost Mix 4.

g. The University of Minnesota experiments show that the pig compost mix allows the temperature to be elevated to thermophilic temperatures. Therefore, the mix will be sufficient to degrade HMX and RDX as well as provide significant reduction in explosive concentrations.

$h$. The radiolabeled TNT studies showed little difference between unlabeled and labeled TNT respiration rate and temperature profile.

i. The reduction in TNT concentration was 47 and 44 percent for unlabeled and labeled TNT, respectively.

\section{Recommendations}

Based on the results of this study, it is recommended that Mix 4 be utilized in the pilot-scale study at IAAP sites. Mixes 3 and 6 may also be proven to be beneficial in a pilot-scale study. Toxicity studies should be conducted to relate the remediation composting engineering design and operation to the quality of compost in terms of target chemical removal and toxicity reduction. 


\section{References}

Alexander, M. (1977). Introduction to soil microbiology. John Wiley, New York.

Arthur, R. M., and Arthur, B. (1994). "Thirty years of respirometry." Proceedings of 49th Purdue industrial waste conference, W. Lafayette, Indiana.

Arthur, R. M., and Meredith, D. (1993). "On-line respirometry." ISA International Conference.

Boening, D., Hendricks, C. W., and Rossignol, A. M. (1995). "Automated respirometer method for microbial toxicity assessment of low-level zinc contamination in soil," Bull. Environmental Contamination Toxicology.

Bollen, G. J. (1985). Composting of agricultural and other wastes. J. K. R. Gasser, ed., Elsevier Applied Science, London.

Brouwer, H., Klapwijk, A., and Keesman, K. J. (1994). "Modeling and control of activated sludge plants on the basis of respirometry," Water Science Technology.

Carlsson, B. (1993). "On-line estimation of the respiration rate in an activated sludge process," Water Science Technology.

Chandler, J. A. et al. (1980). "Predicting methane fermentation biodegradability.” Biotechnology bioengineer symposium. No. 10.

Cook, B. D., Bloom, P. R., and Halback, T. R. (1994). “A method for determining the ultimate fate of synthetic chemicals during composting," Compost Science and Utilization, winter, 42.

Dames and Moore. (1989). "Endangerment assessment, Iowa Army Ammunition Plant, Former Line 1 impoundment and Line 800 Pink Water Lagoon, USATHAMA, Edgewood, MD. 
Doyle, R. C., and Isbister, J. D. (1982). "Treatment of TNT and RDX contaminated soils by composting," Proceeding of national conference on management of uncontrolled hazardous waste sites, Washington, DC.

Finstein, M. S., and Miller, M. C. (1985). Composting of agricultural and other wastes. J. K. R. Gasser, ed., Elsevier Applied Science, London.

Fitzpatrick, G. E. (1993). "A program for determining cocompost belding ratios," Compost Science and Utilization, summer, 30.

Flathman, P. E., and Nowakowski, D. M. (1995). "Electrolytic respirometry taps bioremediation's potential for site cleanup," Environmental Solutions 52.

Forster, C. F., and Wase, D. A. J. (1987). Environmental biotechnology. John Wiley \& Sons, New York.

Garg, R., Grasso, D., and Hoag, G. (1991). "Treatment of explosives contaminated lagoon sludge," Hazardous Waste and Hazardous Materials 8 (4), 319.

Golueke, C. G. (1991). "Principles of composting," The biocycle guide to the art and science of composting. J. Waste Recycling, The JG. Press, Inc., PA.

Grady, C. P. L., Jr., Dang, J. S., Harvey, D. M., Jobbagy, A., and Wang, X. L. (1989). "Determination of biodegradation kinetics through use of electrolytic respirometry," Water Science Technology 21.

Greenburg, A. E., Clesceri, L. S., and Eaton, A. D., Joint Editorial Board. (1992). Standard methods for the examination of water and wastewater. American Public Health Association, Washington, DC.

Hanif, M. (1995). "Focus on composting," Hazardous Technical Information Services, May/June, 7.

Haug, R. T. (1993). The practical handbook of composting engineering. Lewis Publishers, Ann Arbor, MI.

Hogan, J. A., Miller, F. C., and Finstein, M. S. (1989). "Physical modeling of the composting ecosystem," Applied Environmental Microbial. May 1982 .

Hunter, G., Johnson, T., and Carns, K. (1995). "DO probes: Friends or foes," Water Environment Federation, 68th Annual Conference and Exposition, Miami Beach, FL. 
Jacobi, T. A., and Fussa, A. D. (1993). "Low level process wastewater monitoring using total oxygen demand," ISA International Conference 91 .

Jaycor (1993). "Remedial investigation report for the Iowa Army Ammunition Plant," Middletown, IA, Contract No.

DAAAA15-90-D-0006, Vienna, VA.

Kappeler, J., and Gujer, W. (1992). "Estimation of kinetic parameters of heterotrophic biomass under aerobic conditions and characterization of wastewater for activated sludge modeling," Water Science Technology $25(6), 125$.

Kayhanian, M., and Tchobanoglous, G. (1992). "Computation of C/N ratios for various organic fractions," Biocycle, May, 33.

Klapwijk, A., Spanjers, H., and Temmink, H. (1993). "Control of activated sludge plants based on measurements of respiration rates," Water Science Technology 28.

Klein, S. A. (1972). "Anaerobic digestion of solid waste," Compost Science, Jan/Feb, Cited in Haug (1993).

Magalhaes, A. M. T., Shea, P. J., Jawson, M. D., Wicklund, E. A., and Nelson, D. W. (1993). "Practical simulation of composting in the laboratory," Waste Management and Research 11, 143.

Mahendraker, V., and Viraraghavan, T. (1995). "Respirometry in environmental engineering," Journal of Environmental Science and Health A30 (4), 713.

Mathur, S. P. (1991). "Composting processes." Bioconversion of waste materials to industrial products. A. M. Martin, ed., Elsevier Science Publishers LTD., New York.

Pennington, J. C. (1995). "Fate of 2,4,6-trinitrotoluene in a simulated compost system," Chemosphere 30 (3), 429.

Preston, K. T., Seiden, S., and Ro, K. S. (1997). "Bench-scale remediation composting: Process principles and protocol," Technical Report IRRP-97-1, U.S. Army Engineer Waterways Experiment Station, Vicksburg, MS.

Rozich, A. F., and Gaudy, A. F., Jr. (1992). Design and operation of activated sludge processes using respirometry. Lewis Publishers, Ann Arbor, MI.

SCS. (1982). "Underground pollution investigation at Iowa Army Ammunition Plant, Burlington, Iowa," SCS Engineers, Long Beach, CA. 
Spanjers, H., Olsson, G., and Klapwijk, A. (1994). "Determining short-term biochemical oxygen demand and respiration rate in an aeration tank by using respirometry and estimation," Water Resources $28(7), 1571$.

Spanjers, H., Temmink, H., and Klapwijk, A. (1994). "Monitoring of the maximum respiration rate," Water Science Technology 30 (4), 285.

U.S. Army Toxic and Hazardous Material Agency. (1988). "Field demonstration composting of explosive contaminated sediments at Louisiana Army Ammunition Plant (LAAP) Final Report," Contract No. DAAK-11-85-D-007, Report No. AMXTH-IR-TE-88242, Aberdeen Proving Ground, MD.

U.S. Environmental Protection Agency. (1992). "Nitroaromatics and nitramines by high performance liquid chromatography," SW846 Method 8330, Office of Solid Waste and Emergency Response, Washington, DC.

Vanrolleghem, P. A., and Spanjers, H. (1994). "Comparison of two respirometric principles for the determination of short-term biochemical oxygen demand." Proceedings of 49th Purdue Industrial Waste Conference, W. Lafayette, Indiana.

Vanrolleghem, P. A., and Verstraete, W. (1993). "Simultaneous biokinetics characterization of heterotrophic and nitrifying populations of activated sludge with an on-line respirographic biosensor," Water Science Technology 28 (11-12), 377.

Watts, J. B., and Garber, W. F. (1993). "On-line respirometry: a powerful tool for activated sludge plant operation and design," Water Science Technology 28 (11-12), 389. 


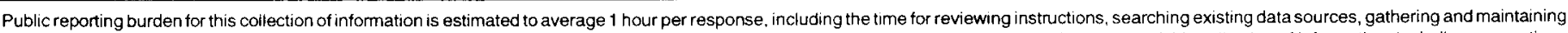

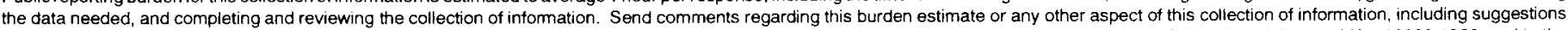

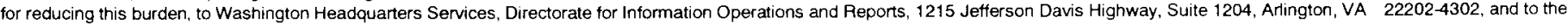
Office of Management and Budget, Paperwork Reduction Project (0704-0188), Washington, DC 20503.

1. AGENCY USE ONLY (Leave blank)

\section{REPORT DATE June 1998}

3. REPORT TYPE AND DATES COVERED

Final report

\section{TITLE AND SUBTITLE}

Bench-Scale Investigation of Composting for Remediation of Explosives-

Contaminated Soil from Iowa Army Ammunition Plant, Middletown, Iowa

6. AUTHOR(S)

Kurt T. Preston, Roy Wade, Kyoung S. Ro, Steve Seiden, Mary Bergess

\section{PERFORMING ORGANIZATION NAME(S) AND ADDRESS(ES)}

U.S. Army Engineer Waterways Experiment Station, 3909 Halls Ferry Road,

Vicksburg, MS 39180-6199; Louisiana State University, Baton Rouge, LA 70803;

North Carolina State University, Raleigh, NC 27607; University of Toledo, Toledo, OH 43606

9. SPONSORING/MONITORING AGENCY NAME(S) AND ADDRESS(ES)

Department of Defense

Iowa Army Ammunition Plant

Middletown, IA 52638
5. FUNDING NUMBERS

\section{SUPPLEMENTARY NOTES}

Available from National Technical Information Service, 5285 Port Royal Road, Springfield, VA 22161.

\section{2a. DISTRIBUTION/AVAILABILITY STATEMENT}

Approved for public release; distribution is unlimited.
8. PERFORMING ORGANIZATION REPORT NUMBER

Technical Report EL-98-7
10. SPONSORING/MONITORING AGENCY REPORT NUMBER

13. ABSTRACT (Maximum 200 words)

Bench-scale compost and radiolabeled studies were conducted at the U.S. Army Engineer Waterways Experiment Station (WES) and at the University of Minnesota to evaluate the reduction of explosives-contaminated soil at Iowa Army Ammunition Plant. The goal of the study was to evaluate and to select the best combination of amendments, contaminated soils, and bulking agents to be utilized in the compost technology for remediation of explosives-contaminated soils. The respirometric test was utilized as a screening tool to provide a general indication of biological activity within eight compost mixtures. The bench-scale compost reactor test was to extend the respirometric study by evaluating the applicability of the screened compost mixtures. The radiolabeled study was to provide insight into the apparent degradation of the explosive contaminant during the composting process. The respirometer results showed that cow manure and corn stalk (Mixture 3) and swine manure and corn stalk (Mixture 4) mixtures outperformed the other mixtures. Mixture 3 showed the best biodegradation rate; Mixture 4 showed the best respiration rate, while its biodegradation rate falls approximately within the middle of the eight treatments. Therefore, Mixtures 3 and 4 were advanced to the bench-scale composting test. The bench-scale composting study validated the explosive removal capacity of Mixtures 3 and 4 . Mixture 3 temperature reached the mesophilic range $\left(40^{\circ} \mathrm{C}\right)$, while Mixture 4 temperature reached the thermophilic range $\left(50^{\circ} \mathrm{C}\right)$. The compost mixtures

(Continued)

\section{SUBJECT TERMS}

Bioavailability

Bioremediation

Composting

Explosives
Substrate rate coefficient Thermophilic
15. NUMBER OF PAGES

49

16. PRICE CODE
Mesophilic

Radiolabel

Respirometry
17. SECURITY CLASSIFICATION 18. SECURITY CLASSIFICATION OF REPORT

UNCLASSIFIED

\section{OF THIS PAGE}

UNCLASSIFIED

NSN 7540-01-280-5500

SECURITY CLASSIFICATION OF ABSTRACT
20. LIMITATION OF ABSTRACT 
13. (Concluded).

returned to ambient temperature after 10 days of composting. The majority of the explosives and transformation products were removed within 15 to 20 days of composting. These results also show that Mixture 3 showed no significant concentration reduction in HMX and RDX probably because of significant heat accumulation in the mix. However, Mixture 4 showed a 77- and 99-percent reduction in HMX and RDX, respectively. The TNT radiolabeled test was conducted on the composted material of Mix 4 and a WES reference soil. These tests were used to prove that Mix 4 would rise to thermophilic temperatures and to determine if any temperature differences would occur between the labeled and unlabeled soils. The radiolabeled TNT studies showed little difference between unlabeled and labeled TNT respiration rate and temperature profile. The results show that the temperature profiles remained at the thermophilic range for approximately 7 days. The TNT concentration was reduced by 97 percent in the Line 1 Impoundment soil. The reduction in TNT concentration was 47 and 44 percent for unlabeled and labeled TNT, respectively. 